\title{
A mechanistic model of coral bleaching due to temperature-mediated light-driven reactive oxygen build-up in zooxanthellae
}

\author{
Mark E. Baird, ${ }^{\mathrm{a}, *}$ Mathieu Mongin ${ }^{\mathrm{a}}$ Farhan Rizwi ${ }^{\mathrm{a}}$ \\ Line K. Bay ${ }^{\text {b Neal E. Cantin }}{ }^{\text {b }}$ Monika Soja-Woźniak ${ }^{a}$ \\ Jennifer Skerratt ${ }^{\mathrm{a}}$ \\ ${ }^{\mathrm{a}}$ CSIRO Oceans and Atmosphere, Hobart 7001, Australia \\ ${ }^{\mathrm{b}}$ Australian Institute of Marine Science, Townsville 4810, Australia
}

\begin{abstract}
Mass coral bleaching has emerged in the 21st century as the greatest threat to the health of the world's reefs. A sophisticated process understanding of bleaching at the polyp scale has now been achieved through laboratory and field studies, but this knowledge is yet to be applied in mechanistic models of shelf-scale reef systems. In this study we develop a mechanistic model of the coral-symbiont relationship that considers temperature-mediated build-up of reactive oxygen species due to excess light, leading to zooxanthellae expulsion. The model explicitly represents the coral host biomass, as well as zooxanthellae biomass, intracellular pigment concentration, nutrient status, and the dynamics of reaction centres and the xanthophyll cycle. Photophysiological processes represented include photoadaptation, xanthophyll cycle dynamics, and reaction centre state transitions. The mechanistic model of the coral-symbiont relationship is incorporated into a $\sim 1 \mathrm{~km}$ resolution coupled hydrodynamic - biogeochemical model that encompasses the entire $\sim 2000 \mathrm{~km}$ length of
\end{abstract}


the Great Barrier Reef. A simulation of the 2016 bleaching event shows the model is able to capture the broadscale features of the observed bleaching, but fails to capture bleaching on offshore reefs due to the model's grid being unable to resolve the bathymetry of shallow platforms surrounded by deep water. To further analyse the model behaviour, a $\sim 200$ m resolution nested simulation of Davies Reef $\left(18^{\circ} 49^{\prime} \mathrm{S}, 147^{\circ} 38^{\prime} \mathrm{E}\right)$ is undertaken. We use this nested model to demonstrate the depth gradient in zooxanthellae response to thermal stress. Finally, we discuss the uncertainties in the bleaching model, which lie primarily in quantifying the link between reactive oxygen build-up and the expulsion process. Through the mechanistic representation of environmental forcing, this model of coral bleaching applied in realistic environmental conditions has the potential to generate more detailed predictions than the presently-available satellite-based coral bleaching metrics, and can be used to evaluate proposed management strategies.

Key words: Symbiodinium; mass bleaching; biogeochemical model; climate change; coral mortality; Great Barrier Reef

\section{$1 \quad 1$ Introduction}

2 Coral bleaching is the expulsion of the unicellular zooxanthellae symbiont 3 from the coral host, often leading to mortality. The link between a warming

4 surface ocean and mass bleaching events had became obvious after the 1998 5 global event. It was possible in 1999 to predict from climate model simulations 6 that the thermal tolerances of reef-building corals were likely to be exceeded 7 every year within a few decades, and that events as severe as the 1998 event 8 would likely become commonplace within 20 years (Hoegh-Guldberg, 1999). 9 This 1999 prediction of an unprecedented future has eventuated in the late * Corresponding author: mark.baird@csiro.au 
2010s (Hughes et al., 2017). Thus the broadscale patterns of mass bleaching are predictable on decadal scales.

New management strategies under consideration for coral reef protection include prioritising those individual reefs that are more resilient to future threats (Hock et al., 2017). Thus it is urgent that we are able to identify reefs with lower thermal stress, or other environmental conditions such as good water clarity, that lead to greater resilience. Furthermore, active intervention strategies are being considered that include the introduction of temperaturetolerant individuals or species (Anthony et al., 2017; van Oppen et al., 2017). To predict the success of these interventions requires models of coral-symbiont bleaching dynamics that explicitly consider the tolerance-enabling trait, such as sensitivity to reactive oxygen concentration. Further these bleaching models must be applied in a realistic, spatially-resolved environmental setting to optimise deployment.

Historically, process-based modelling of the coral-symbiont relationship has received relatively little attention compared to other aquatic ecosystem-building functional groups such as seagrass or phytoplankton (e.g. Madden and Kemp (1996); Baird et al. (2003)). This oversight is being addressed with the increasing awareness of the impacts of climate change on the coral-symbiont relationship. The coral-symbiont relationship was first modelled using a dynamic energy budget approach (Muller et al., 2009; Eynaud et al., 2011). Gustafsson et al. (2013) also explicitly modelled the coral-symbiont relationship, and included some more mechanistic process description such as diffusive limitation of nutrient uptake. Gustafsson et al. (2014) added photo-oxidative stress, and in particular the xanthophyll cycle, reaction centre dynamics and reactive oxygen build-up, to their earlier work, showing that heterotrophic feeding 
provided protection from temperature-enhanced photo-oxidative stress. Most recently, Cunning et al. (2017) have also shown that the balance of autotrophic and heterotrophic nitrogen sources influences the steady-state of the coralsymbiont system, where bleached or unbleached are two final states.

The process-based models of the coral-symbiont relationship cited above have been undertaken by considering one polyp in isolation, allowing comparison to laboratory experiments, but the output of these one polyp simulations are not easily compared to observations from natural coral reefs. A simplified form of the Gustafsson et al. (2013) model has been implemented in a Great Barrier Reef (GBR) scale model (Baird et al., 2016b; Mongin et al., 2016), but the dynamics of the coral themselves in this complex biogeochemical model has only been briefly analysed (Herzfeld et al., 2016). In order to understand the mass bleaching occurring on reefs around the world, and to support a range of management actions, it is necessary to apply process-based coral-symbiont models that consider temperature-mediated light-driven oxidative stress within biogeochemical / ecosystem models that are capable of predicting the time-varying light, nutrient and prey conditions of natural reef environments.

A large, multi-agency collaboration has developed the eReefs coupled hydrodynamic, sediment and biogeochemical model that simulates at multiple scales the environmental conditions of the Great Barrier Reef (Schiller et al., 2014). The project provides $\sim 1$ and $\sim 4 \mathrm{~km}$ resolution hindcast and near real time simulations of hydrodynamic and biogeochemical quantities (www.ereefs.info). The models provides skilful predictions of the drivers of coral processes such as temperature, spectrally-resolved bottom light, and water column concentrations of dissolved inorganic nutrients and particulate 
organic matter across the entire length of the Great Barrier Reef from 2011present (Skerratt et al., submitted). Furthermore, the eReefs project includes bespoke model generation that allows high-resolution models to be nested within the $1 \mathrm{~km}$ regional hindcast (RECOM - RElocatable Coastal Ocean Model).

In this paper, we develop a process-based model of the coral-symbiont relationship that considers temperature-mediated light-driven oxidative stress resulting in zooxanthellae expulsion. The model explicitly represents the coral host and the zooxanthellae biomass, pigment concentration, nutrient status, as well as the reaction centre and xanthophyll cycle dynamics. The process-based model of the coral-symbiont relationship is incorporated into the eReefs 3D coupled hydrodynamic - biogeochemical model of the Great Barrier Reef, and a simulation run of the 2016 bleaching event in the $\sim 1 \mathrm{~km}$ configuration and a $\sim 200 \mathrm{~m}$ Davies Reef configuration. The model behaviour is analysed at both scales, and model uncertainty discussed. Finally, with a model that captures the impact of temperature, solar radiation and water column inorganic and particulate nutrients on coral bleaching, we consider future applications in the management of the Great Barrier Reef.

\section{Model description}

1 The ultimate purpose of the mechanistic model of coral bleaching developed in this paper is to be able to predict bleaching in natural environments, and to explore the impact of interventions to reduce bleaching. This requires a model that responds to water column conditions such as nutrients, light and temperature, and produces metrics of stress such as concentration of reactive 
oxygen species and zooxanthellae expulsion rates.

The coral-symbiont model developed here is an extension of the coral polyp model of Gustafsson et al. (2013) and the photosystem bleaching model of Gustafsson et al. (2014). Further we have included the photoadaption model of Baird et al. (2013) and the multiple nutrient limitation microalgae model of Baird et al. (2016b). This combination of process descriptions is applied in a complex biogeochemical model of the Great Barrier Reef that has been described elsewhere (Mongin et al., 2016), and was developed in the eReefs Project (Schiller et al., 2014).

The following description of the coral-symbiont model description is split into three sections: (1) the interactions between the coral host, the symbiont and the environment; (2) photoadaptation through pigment synthesis and the xanthophyll cycle; and (3) photosynthesis, reaction centre dynamics and reactive oxygen production leading to zooxanthellae expulsion.

\subsection{Coral host, symbiont and the environment}

The state variables for the coral polyp model (Table A.1) include the biomass of coral tissue, $\mathrm{CH}\left(\mathrm{g} \mathrm{N} \mathrm{m}^{-2}\right)$, and the structure material of the zooxanthellae cells, $C S\left(\mathrm{mg} \mathrm{N} \mathrm{m}^{-2}\right)$. The structure material of the zooxanthellae, $C S$, in addition to nitrogen, contains carbon and phosphorus at the Redfield ratio.

The zooxanthellae cells also contain reserves of nitrogen, $R_{N}\left(\mathrm{mg} \mathrm{N} \mathrm{m}^{-2}\right)$, phosphorus, $R_{P}\left(\mathrm{mg} \mathrm{P} \mathrm{m}{ }^{-2}\right)$, and carbon, $R_{C}\left(\mathrm{mg} \mathrm{C} \mathrm{m}^{-2}\right)$.

The zooxanthellae light absorption capability is resolved by considering the time-varying concentrations of pigments chlorophyll $a, C h l$, diadinoxanthin, 
$X_{p}$, and diatoxanthin $X_{h}$, for which the state variable represents the areal concentration. A further three pigments, chlorophyll $c_{2}$, peridinin, and $\beta$-carotene are considered in the absorption calculations, but their concentrations are in fixed ratios to chlorophyll $a$. Exchanges between the coral community and the overlying water can alter the water column concentrations of dissolved inorganic carbon, $D I C$, nitrogen, $N$, and phosphorus, $P$, as well as particulate phytoplankton, $B$, zooplankton, $Z$, and detritus, $D$, where multiple nitrogen, plankton and detritus types are resolved (Table A.1).

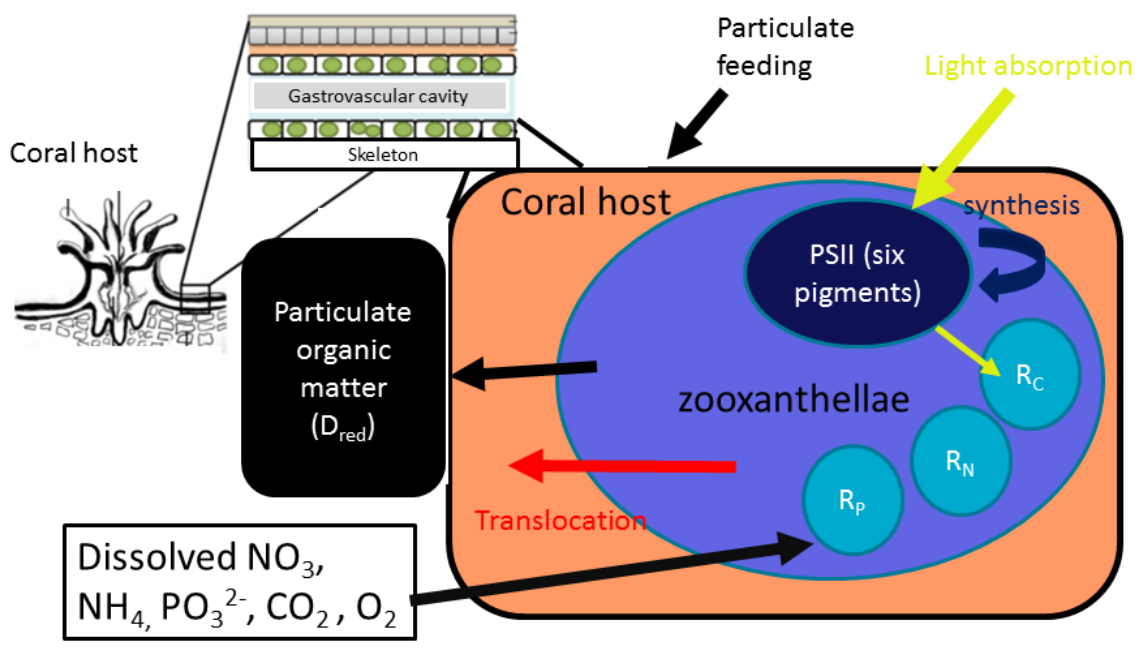

Fig. 1. Schematic showing the coral-symbiont relationship and its interaction with the overlying water column.

The coral host is able to assimilate organic nitrogen either through translocation from the zooxanthellae cells or through the capture of water column organic detritus and/or plankton (Fig. 1). The zooxanthellae varies its intracellular pigment content depending on potential light limitation of growth, and the incremental benefit of adding pigment, allowing for the package effect (Baird et al., 2013). The coral tissue is assumed to have a Redfield C:N:P stoichiometry (Redfield et al., 1963), as shown by Muller-Parker et al. (1994). The zooxanthellae are modelled with variable C:N:P ratios (Muller-Parker et al., 
1994), based on a structure material at the Redfield ratio, but with variable internal reserves. The fluxes of $\mathrm{C}, \mathrm{N}$ and $\mathrm{P}$ with the overlying water column (nutrient uptake and detritial / mucus release) can therefore vary from the Redfield ratio.

An explanation of the individual processes follows, with tables in the Appendix listing all the model state variables (Table A.1), derived variables (Table A.2), equations (Tables A.3, A.4, A.5 and A.6), and parameters values (Tables A.7 and A.8).

\subsubsection{Effective projected area fraction of corals}

A key component of the coral-symbiont model is to relate the biomass of the polyp to coral cover (the fraction of the bottom covered when viewed from above). This relationship is important as it determines, for a given biomass of coral host, the area of the bottom the polyp covers. The bottom cover impacts on the nutrient flux from the water column, and limits the number of zooxanthellae per unit area. Following the derivation of Baird et al. (2016a), we use a mathematical form that captures the likelihood that an independentlyplaced polyp will lie over the top of another polyp, and is similar to a Poisson distribution:

$$
A_{e f f}=1-\exp \left(-\Omega_{C H} C H\right)
$$

where $A_{\text {eff }}$ is the effective projected area fraction of the coral community $\left(\mathrm{m}^{2}\right.$ $\mathrm{m}^{-2}$ ), $C H$ is the biomass of the coral host, and $\Omega_{C H}$ is the nitrogen-specific polyp area coefficient $\left(\mathrm{m}^{2} \mathrm{~g} \mathrm{~N}^{-1}\right)$.

In the coarser configurations, coral communities are restricted to a size that 


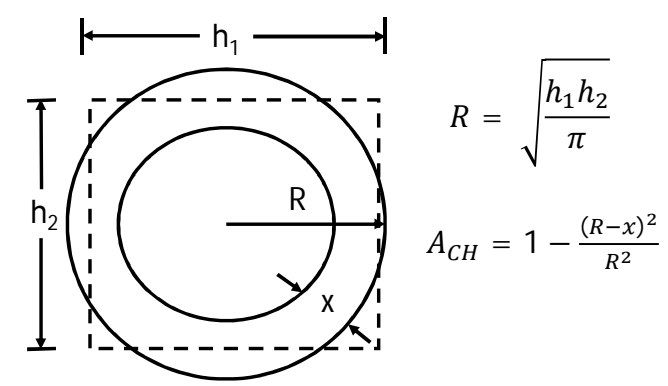

Fig. 2. Schematic showing the geometric calculation of the sub-grid parameterisation of the effective projected area fraction of corals, $A_{C H}$. Nominal width of dense coral communities, $x=200 \mathrm{~m}$, grid cell dimensions $h_{1}$ and $h_{2}$ are $1000 \mathrm{~m}$ for the $1 \mathrm{~km}$ grid, and $R$ is the equivalent circular radius of the grid cell.

is often much less than the model grid size, due to their existence on the rims of reefs (Baird et al., 2004b). To consider this sub-grid scale patchiness, Eq. 1 is slightly modified resulting in the effective projected area for corals calculated by:

$$
A_{e f f}=A_{C H}\left(1-\exp \left(-\Omega_{C H} C H / A_{C H}\right)\right)
$$

The area coefficient, $A_{C H}$, represents the fraction of a grid cell that the corals can occupy. In the case of $200 \mathrm{~m}$ grids, this will be up to 1, representing dense corals on the whole cell. For coarser grids, $A_{C H}$ is reduced to represent that the cell contains both dense coral communities on the forereef / reef crest and also sparse coral communities on the reef flat / lagoon areas. In the $1 \mathrm{~km}$ grid, $A_{C H}$ represents the fraction of the area of dense corals to total reef area, and is of order 0.36 . The geometrically-derived equation for $A_{C H}$ is given by (Fig. 2):

$$
A_{C H}=1-\frac{(R-x)^{2}}{R^{2}}, \quad R=\sqrt{h_{1} h_{2} / \pi}, \quad R>x
$$

where $x$ is the width of dense coral communities on the reef, and $R$ is the equivalent circular radius of the grid cell.

The impact of concentrating corals into one portion of a grid cell, as quan- 
tified by $A_{C H}$, only affects the calculations when the concentrated area begins self-shading. Thus, in Eq. 2, when $\Omega_{C H} C H / A_{C H}$ is small, $A_{e f f} \sim(1-$ $\exp \left(-\Omega_{C H} C H\right)$. But if $\Omega_{C H} C H / A_{C H} \rightarrow 1$ and $A_{C H}<1$ the coral biomass saturates due to space limitation at a lower biomass than it would for $A_{C H}=1$.

The eReefs model contains macroalgae that grow above the corals at the seabed. For the case of macroalgae over-growing corals, the effective projected area occupied by corals is further reduced by the presence of macroalgal leaves:

$$
A_{e f f}=A_{C H} \exp \left(-\Omega_{M A} M A\right)\left(1-\exp \left(-\Omega_{C H} C H / A_{C H}\right)\right)
$$

where $M A$ is the biomass of macroalgae, and $\Omega_{M A}$ is the nitrogen-specific leaf area coefficient $\left(\mathrm{m}^{2} \mathrm{~g} \mathrm{~N}^{-1}\right)$. We assume that the fraction of the bottom covered by the macroalgae, $\exp \left(-\Omega_{M A} M A\right)$, is evenly spread across the surface. Thus the portion covered by corals is also reduced by the same factor, resulting in the multiplication of the $\exp \left(-\Omega_{M A} M A\right)$ and $A_{C H}\left(1-\exp \left(-\Omega_{C H} C H / A_{C H}\right)\right)$ in Eq. 4. In the eReefs biogeochemical model, the macroalgae is parameterised more like a filamentous epiphytic macroalgae rather than a leafy seaweed. Larger seaweeds, including Halimeda beds that are extensive in the northern GBR (McNeil et al., 2016), may exclude the corals (or seagrasses) via a different mechanisms than captured in Eq. 4, but are not represented in the model.

\subsubsection{Growth rate of zooxanthellae cells}

The model considers the diffusion-limited supply of dissolved inorganic nutrients $(\mathrm{N}$ and $\mathrm{P}$ ) and the absorption of light, delivering $\mathrm{N}, \mathrm{P}$ and fixed $\mathrm{C}$ to the internal reserves of the cell (Fig. 1). Nitrogen and phosphorus are taken directly into the reserves, but carbon is first fixed through photosynthesis (Kirk, 
1994):

$$
106 \mathrm{CO}_{2}+212 \mathrm{H}_{2} \mathrm{O} \stackrel{1060 \text { photons }}{\longrightarrow} 106 \mathrm{CH}_{2} \mathrm{O}+106 \mathrm{H}_{2} \mathrm{O}+138 \mathrm{O}_{2}
$$

More on Eq. 5 is derived in Sec. 2.2.2. The internal reserves of $\mathrm{C}, \mathrm{N}$, and $\mathrm{P}$ are consumed to form structural material at the Redfield ratio (Redfield et al., 1963):

$$
\begin{aligned}
106 \mathrm{CH}_{2} \mathrm{O}+16 \mathrm{NO}_{3}^{-}+\mathrm{PO}_{4}^{3-}+16 \mathrm{H}_{2} \mathrm{O}+19 \mathrm{H}^{+} & \stackrel{(6)}{\stackrel{1060 \text { photons }}{\longrightarrow}}\left(\mathrm{CH}_{2} \mathrm{O}\right)_{106}\left(\mathrm{NH}_{3}\right)_{16} \mathrm{H}_{3} \mathrm{PO}_{4}
\end{aligned}
$$

Note that while oxygen balances across the two equations, the oxygen released from $\mathrm{NO}_{3}^{-}$in Eq. 6 appears as a product in the photosynthesis equation (Eq. 5). Ignoring this small mismatch in time of oxygen production simplifies the model equations while maintaining oxygen conservation.

The growth rate of a microalgae cell is given by the maximum growth rate, $\mu^{\text {max }}$, multiplied by the normalised reserves, $R^{*}$, of each of $\mathrm{N}, \mathrm{P}$ and $\mathrm{C}$ :

$$
\mu=\mu^{\max } R_{N}^{*} R_{P}^{*} R_{C}^{*}
$$

\footnotetext{
Fig. 3 is a simple schematic showing the impact of growth alone on internal reserves for a population of two cells growing into exactly three cells, although the equations are continuous in time for a population. The mass of the reserves (and therefore the total C:N:P:Chl $a$ ratio) of the cell depends on the interaction of the supply and consumption rates. When consumption exceeds supply, and the supply rates are non-Redfield, the normalised internal reserves of the non-limiting nutrients approach 1 while the limiting nutrient becomes
} 


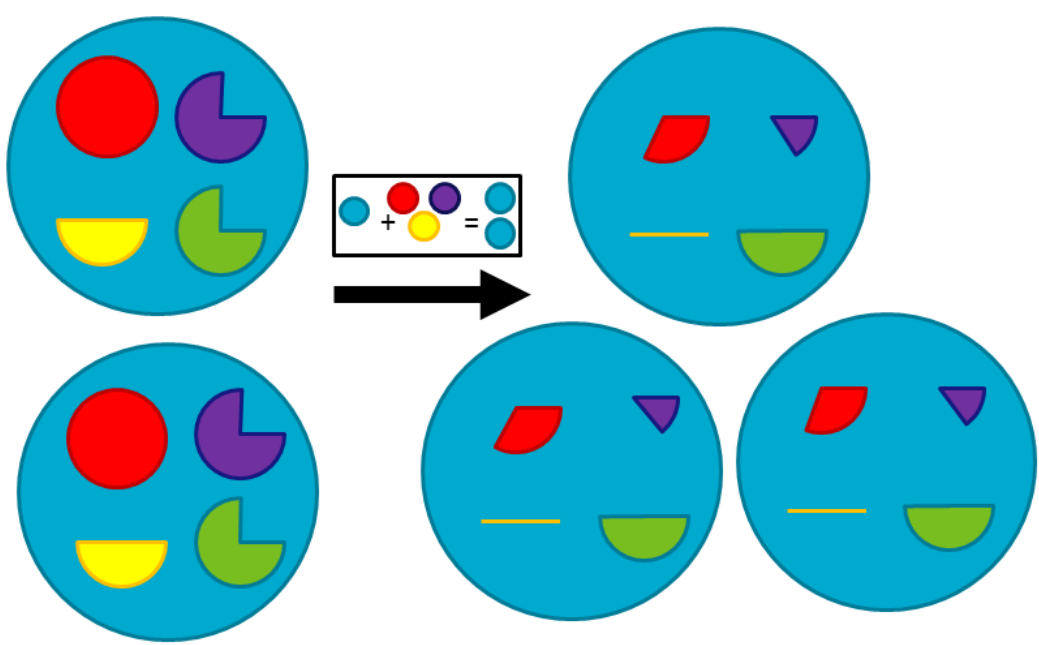

Fig. 3. Schematic of the process of microalgae growth from internal reserves. Blue circle - structural material; Red pie - nitrogen reserves; Purple pie - phosphorus reserves; Yellow pie - carbon reserves; Green circle - pigment content. Here a full pie has a value of 1 , representing the normalised reserve (a value between 0 and 1 ). The box shows that to generate structural material for an additional cell requires the equivalent of $100 \%$ internal reserves of carbon, nitrogen and phosphorus of one cell. This figure shows the discrete growth of 2 cells to 3, requiring both the generation of new structural material from reserves and the reserves being diluted through the number of cells in which they are divided increasing from 2 to 3 . Thus the internal reserves for nitrogen after the population increases from 2 to 3 is given by: two from the initial 2 cells, minus one for building structural material of the new cell, shared across the 3 offspring, to give $1 / 3$. The same logic applies to carbon and phosphorus reserves, with phosphorus reserves being reduced to $1 / 6$, and carbon reserves being exhausted. In contrast, pigment is not required for structural material so the only reduction is through dilution; the $3 / 4$ content of 2 cells is shared among 3 cells to equal $1 / 2$ in the 3 cells. This schematic shows one limitation of a population-style model whereby reserves are 'shared' across the population (as opposed to individual based modelling, Beckmann and Hense (2004)). A proof of the conservation of mass for this scheme, including under mixing of populations of suspended microalgae, is given in Baird et al. (2004a). The model equations also include terms affecting internal reserves through nutrient uptake, light absorption, respiration and mortality that are not shown in this simple schematic. 


\subsubsection{Uptake of nutrients and particulate matter from the overlying water}

The maximum flux of nutrients and prey to the surface of the coral is specified as a mass transfer limit per projected area of coral (Atkinson and Bilger, 1992; Baird et al., 2004b), as given by (Falter et al., 2004; Zhang et al., 2011):

$$
S_{\mathrm{x}}=2850\left(\frac{2 \tau}{\rho}\right)^{0.38} \mathrm{Sc}_{\mathrm{x}}{ }^{-0.6}, \mathrm{Sc}_{\mathrm{x}}=\frac{\nu}{D_{\mathrm{x}}}
$$

where $S_{\mathrm{x}}$ is the mass transfer rate coefficient of element $\mathrm{x}=\mathrm{N}, \mathrm{P}, \tau$ is the shear stress on the bottom, $\rho$ is the density of water and $\mathrm{Sc}_{\mathrm{x}}$ is the Schmidt number. The Schmidt number is the ratio of the diffusivity of momentum, $\nu$, and mass, $D_{\mathrm{x}}$, and varies with temperature, salinity and nutrient species. The mass transfer rate constant $S_{x}$ can be thought of the height of water cleared of nutrient per unit of time by the water-coral exchange.

The capture of organic particles (phytoplankton, zooplankton, labile detritus) is also represented as an areal flux. Ribes and Atkinson (2007) considered whether mass transfer limits apply to particulate matter on reefs, and found for coral rubble communities only a weak velocity dependence, suggesting filter feeders overcame any diffusion limitations (see also Monismith et al. (2010)). Thus, instead of using a velocity-dependent mass transfer rate like was used for dissolved tracers (Eq. 9), capture of organic particles, $G$, is represented by a constant mass transfer rate coefficient, $S_{\text {part }}$, multiplied by the sum of the concentration of each of organic constituents in the water column. The calculated capture rate is limited to the maximum growth rate of the coral tissue, $\mu_{C H}^{\max } \mathrm{CH}$ (Table A.4).

The maximum fluxes of both nutrients and particulates from the overlying water are multiplied by the effective projected area fraction of the coral $\left(A_{\text {eff }}\right)$ 
to account for corals covering only a fraction of the bottom.

\subsubsection{Translocation between zooxanthellae and coral host}

Translocation here represents the one-way consumption of zooxanthellae organic matter produced through either zooxanthellae growth or mortality.

A fraction, $f_{\text {tran }}$, of zooxanthellae growth is translocated to the coral tissue. This fraction is given by the ratio of the projected area of the zooxanthellae cells to twice the surface area of the coral polyp, $2 \mathrm{CH} \Omega_{C H}$ :

$$
f_{\text {tran }}=\frac{\pi r_{C S}^{2} C S / m_{N}}{2 C H \Omega_{C H}}
$$

where $r_{C S}$ is the radius of the zooxanthellae cells. When $f_{\text {tran }}<0.5$, zooxanthellae growth is primarily used for increasing symbiont population, and for $f_{\text {tran }}>0.5$, it is primarily translocated. The initial number of symbiont cells is set so that $\left(\pi r_{C S}^{2} C S / m_{N}\right) /\left(2 C H \Omega_{C H}\right)$ is less than 1. Under this initial condition, as $\left(\pi r_{C S}^{2} C S / m_{N}\right) /\left(2 C H \Omega_{C H}\right)$ approaches 1, all symbiont growth is translocated, so $f_{\text {tran }}$ never has a value above 1 .

This translocation formulation represents a geometrically-derived space limitation on zooxanthellae, being located within two layers of gastrodermal cells (Gustafsson et al., 2013). The geometric derivation has avoided the need for uncertain and/or poorly-defined mass-specific space limitation coefficients.

\subsubsection{Coral polyp net production}

Coral host biomass, $\mathrm{CH}$, grows at a maximum rate, $\mu_{C H}^{\max } \mathrm{CH}$, conditional on the availability of organic matter either taken up from the water column as particulate organic matter by the host itself (Eq. 9), or through translocation 
from zooxanthellae. It is assumed that the realised hetertrophic feeding rate of zooxanthellae, $G^{\prime}$, is independent of the physiology of the coral host, and further, that the fraction of the zooxanthellae growth that is translocated depends only on the unavailability of space for the zooxanthellae population to reside in (see above).

$$
G^{\prime}=\min \left[\min \left[\mu_{C H}^{\max } C H-f_{\text {tran }} \mu_{C S} C S-\zeta_{C S} C S, 0\right], G\right]
$$

Should this rate of translocation, plus the flux of organic matter due to zooxanthellae mortality, exceed the maximum growth rate of coral host biomass, $\mu_{C H}^{\max } \mathrm{CH}$, then the coral host grows at its maximum rate, and the excess is released into the environment as mucus. Should the translocation rate and the particulate organic matter flux be less than $\mu_{C H}^{\max } \mathrm{CH}$, then the coral host grows at the sum of the two. Finally, should the sum of the translocation rate and the particulate organic matter flux be greater than $\mu_{C H}^{\max } \mathrm{CH}$, then the host will use all of the translocated organic matter, and a fraction of captured particulate organic matter, with the fraction being composed of fractions of each particulate components based on the relative concentration of organic matter in each category.

\subsubsection{Non-bleaching mortality of coral polyps}

There are two mortality terms: the mortality of the entire polyp $\left(\zeta_{C H}\right)$, affecting both coral and zooxanthellae biomass, and mortality of the zooxanthellae $\left(\zeta_{C S}\right)$. The polyp mortality term has a quadratic mortality coefficient, $\zeta_{C H}$, that stabilises the biomass of coral tissue to $\mu_{C H} / \zeta_{C H}$. For a maximum growth rate of coral, $\mu_{C H}^{\max }=0.05 \mathrm{~d}^{-1}, \zeta_{C H}$ has been set to $0.01\left(\mathrm{~g} \mathrm{~N} \mathrm{~m}^{-2}\right)^{-1} \mathrm{~d}^{-1}$, so the biomass of coral tissue $C H$ stabilises at $0.05 / 0.01=5 \mathrm{~g} \mathrm{~N} \mathrm{~m}^{-2}$. As this 
biomass is per unit area, and includes a correction for corals being only viable on $A_{e f f}$ of the area, $\zeta_{C H}$ needs to be divided by $A_{e f f}$ in the equations.

The model does not consider coral host mortality due to thermal stress directly. The impact of zooxanthellae expulsion on the host is a reduced translocation of organic matter from the symbiont to the host, reducing growth if heterotrophic feeding is growth limiting.

\subsection{Photoadaptation through pigment synthesis and the xanthophyll cycle}

The model considers the photoacclimation or photoadaptation of the zooxanthellae cells through the processes of pigment synthesis and xanthophyll pigment cycling (Fig. 4, left). The model assumes a constant ratio of xanthophyll pigments to chlorophyll, $\Theta_{\text {chl2xan }}$. This ratio is maintained constant through time by assuming xanthophyll synthesis is $\Theta_{\text {chl2xan }}$ multiplied by the chlorophyll synthesis. For simplicity we assume all synthesised xanthophyll is of the photosynthesising form. Similarly, a constant ratio of synthesis of peridinin, chlorophyll $c_{2}$ and $\beta$-carotene accessory pigments to chlorophyll $a$ ensures these accessory pigments also maintain a constant ratio. The de-coupling of zooxanthellae growth and pigment synthesis results in a variable carbon to chlorophyll ratio through time.

The rate of synthesis of pigment is based on the incremental benefit of adding pigment to the rate of photosynthesis. This calculation includes a reduced benefit when carbon reserves are replete, $\left(1-R_{C}^{*}\right)$, the reduced benefit due to self-shading, $\chi$, and the fraction of inhibited reaction centres, $\left(Q_{i n} / Q_{T}\right)$. The factor $\chi$ is calculated for the derivative of the absorption cross-section per unit projected area, $\alpha / P A$, with non-dimensional group $\rho=\gamma c_{i} r$. For a sphere of 


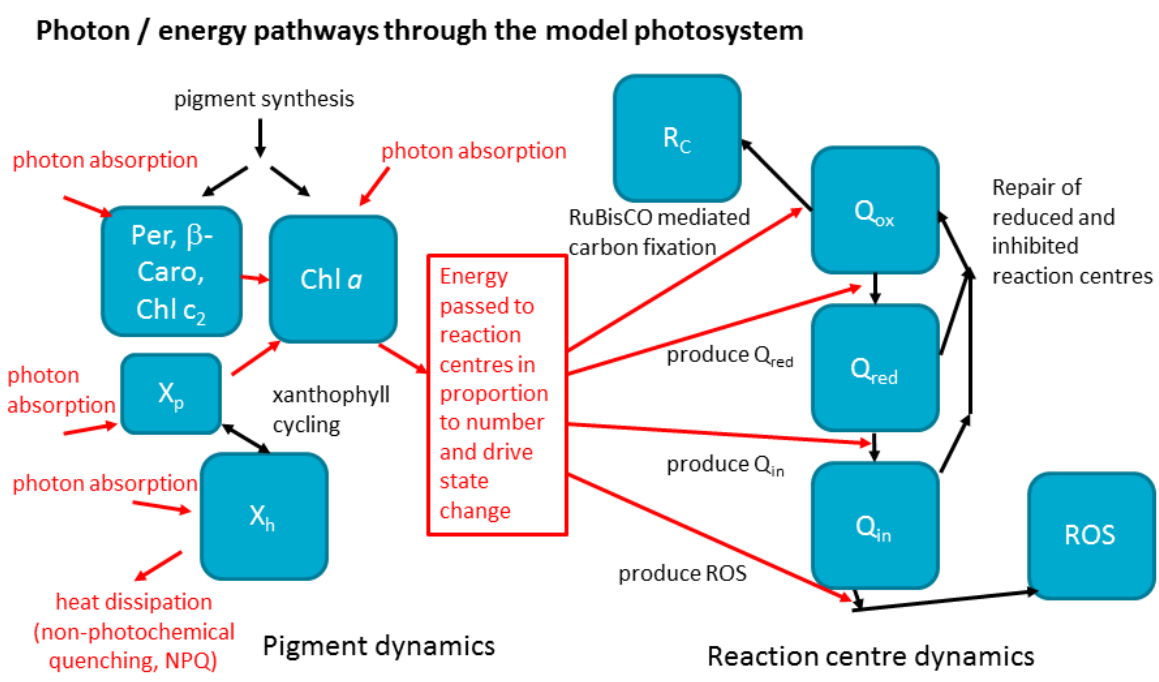

Fig. 4. Schematic showing photosynthetic (Chl $a$, peridinin, $\beta$-carotene, Chl $c_{2}$, and the photosynthetic xanthophyll diadinoxanthin, $\left.X_{p}\right)$ and the photoprotective (xanthophyll diatoxanthin, $X_{h}$ ), xanthophyll cycling and reaction centre dynamics. Red arrows depict fluxes of photons / electrons. Black arrows show transformations of state of either reaction centres or xanthophyll cycle pigments. Note that energy (or photons) are conserved in this flow, significantly reducing the need for empirical rate constants.

radius $r$ (Baird et al., 2013):

$$
\frac{1}{P A} \frac{\partial \alpha}{\partial \rho}=\frac{1-e^{-2 \rho}\left(2 \rho^{2}+2 \rho+1\right)}{\rho^{3}}=\chi
$$

where $\chi$ represents the area-specific incremental rate of change of absorption with $\rho$. For the multi-spectral calculation used in this paper, we calculate the quantum-weighted mean of $\chi, \bar{\chi}$.

The rate of chlorophyll synthesis is given by:

$$
\frac{\partial c_{i}}{\partial t}=k_{\mathrm{Chl}}^{\max }\left(1-R_{C}^{*}\right)\left(1-Q_{i n} / Q_{T}\right) \bar{\chi} \quad \text { if } \mathrm{C}: \mathrm{Chl}>\theta_{\text {min }}
$$

where $k_{\mathrm{Chl}}^{\max }$ is the maximum rate of synthesis and $\theta_{\min }$ is the minimum $\mathrm{C}: \mathrm{Chl}$ ratio. Below $\theta_{\min }$, pigment synthesis is zero. Both self-shading, and the rate of photosynthesis itself, are based on photon absorption rather than energy ab- 


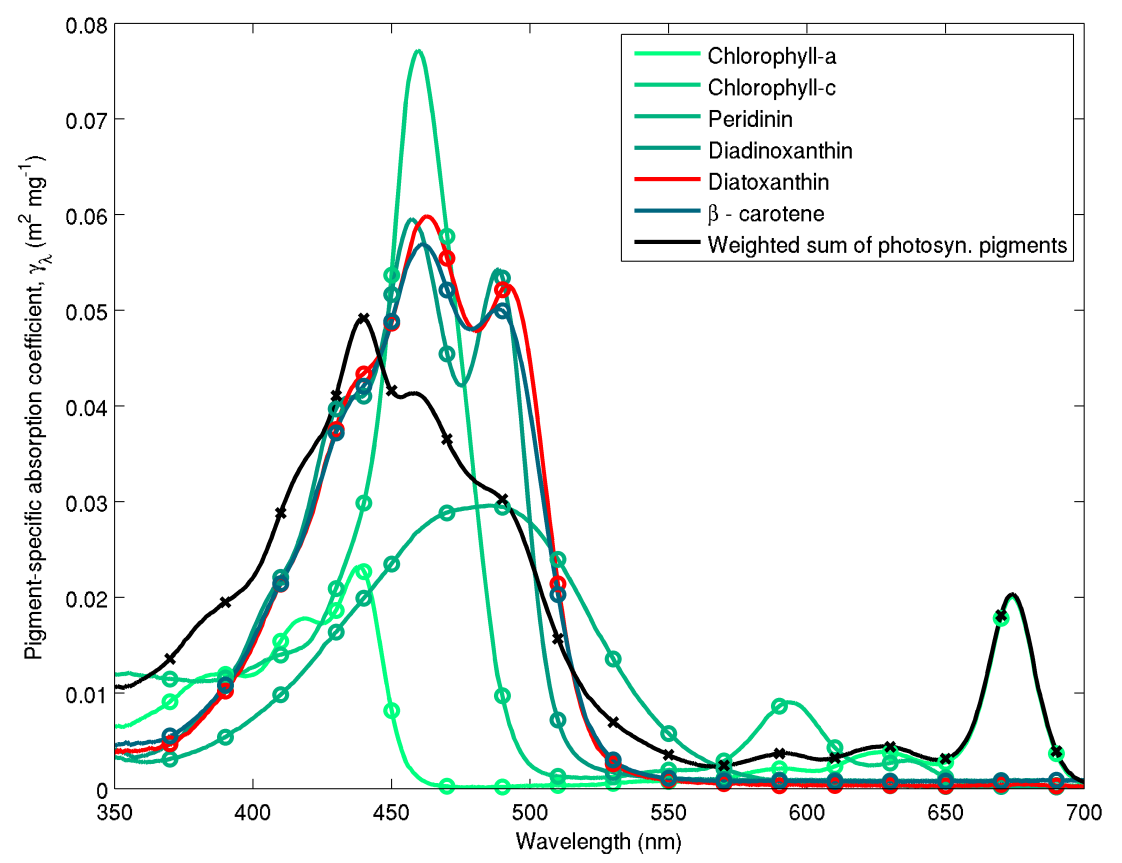

Fig. 5. Pigment-specific absorption coefficients for the dominant pigments found in Symbiodinium determined using laboratory standards in solvent in a $1 \mathrm{~cm}$ vial undertaken. Green lines are photosynthetic pigments, red lines are photoprotective pigments constructed from 563 measured wavelengths. Circles represent the wavelengths at which the optical properties are calculated in the simulations. The black line represents the weighted sum of the photosynthetic pigments (Eq. 18), with the weighting calculated from the ratio of each pigment concentration to chlorophyll $a$. Black crosses represent the chl $a$-specific absorption coefficient of all pigments at the wavelengths used in the simulations. The spectra are wavelength-shifted from their raw measurement by the ratio of the refractive index of the solvent to the refractive index of water (1.352 for acetone used with chlorophyll $a$, chlorophyll $c_{2}$ and $\beta$-carotene; 1.361 for ethanol used with peridinin, diadinoxanthin and diatoxanthin; 1.330 for water). The integral from 340 to $700 \mathrm{~nm}$ of the chl $a$-specific absorption coefficient using the 23 model wavelengths is only $0.72 \%$ greater than using the 563 measured wavelengths. Thus for white light incident on cells with a zero package effect, 23 wavelengths is sufficient to compute the spectrally-resolved absorption. For highly packaged cells, the absorption cross-section is flattened (Kirk, 1994), so the error will be even less than $0.72 \%$.

The symbiont cell contains six pigments, chlorophyll $a$, chlorophyll $c_{2}$, peri- 
dinin, $\beta$-carotene and diadinoxanthin that absorb light and pass the photons on through the photosystem; and diatoxanthin, that absorbs light and dissipates it as heat. Diadinoxanthin and diatoxanthin are almost identical molecules. Diatoxanthin is the de-epoxidised form of diadinoxanthin. The xanthophyll cycle (Falkowski and Raven, 2007) is the reversible switching of diadinoxanthin to diatoxanthin under potentially damaging excess light, and vice-versa under light-limiting conditions. The xanthophyll cycle in the model is represented by two state variables, the areal concentration of diadinoxanthin $\left(X_{p}\right)$ and of diatoxanthin $\left(X_{h}\right)$, and requires one new parameter, $\tau_{x a n}$, the time-scale of switching.

The rate at which the xanthophyll pigments switch from diadinoxanthin to diatoxanthin (or vice versa) is assumed to be relatively fast when compared to the synthesis of pigments. The reversible processes is given by:

$$
\frac{\partial X_{p}}{\partial t}=-8\left(Q_{i n} / Q_{\mathrm{T}}-0.5\right)^{3} \tau_{x a n} \Phi\left(X_{p}+X_{h}\right)=-\frac{\partial X_{h}}{\partial t}
$$

where the time scale, $1 / \tau_{x a n}$, is order of 10 minutes (Gustafsson et al., 2014). The direction of switching in Eq. 14 is set by the term $\left(Q_{i n} / Q_{\mathrm{T}}-0.5\right)^{3}$, such that cells with a large fraction of inhibited reaction centres $\left(Q_{i n} / Q_{\mathrm{T}}>0.5\right)$ switch from diadinoxanthin $\left(X_{p}\right)$ to diatoxanthin $\left(X_{h}\right)$, and a small fraction of oxidised reaction centres vice versa. The term $8\left(Q_{\text {in }} / Q_{\mathrm{T}}-0.5\right)^{3}$ also increases cubically from zero to 1 (for $Q_{i n} / Q_{\mathrm{T}}>0.5$ ) or decreases from zero to -1 (for $\left.Q_{\text {in }} / Q_{\mathrm{T}}<0.5\right)$ as the cell becomes more or less inhibited respectively. Using a cubic power that takes a small value in the vicinity of 0.5 prevents fast switching between diadinoxanthin $\left(X_{p}\right)$ and diatoxanthin $\left(X_{h}\right)$ in the region of 0.5 . The constant 8 arises from $8 \times 0.5^{3}=1$, where 3 is the cubic power. A odd power is necessary to retain the direction of switching. 
The final bracketed term, $\left(X_{p}+X_{h}\right)$, recognises that the switching is quantified for the population of cells, and so is proportional to the total xanthophyll pigment concentration of the population.

Finally, the rate of conversion slows as one pigment pool is reduced to zero, as determined by a parabolic term $\Phi$ (Eq. 15). If $Q_{i n} / Q_{\mathrm{T}}<0.5$ and $X_{h}>X_{p}$ (i.e. uninhibited reaction centres with more heat dissipating than light absorbing pigment) or $Q_{i n} / Q_{\mathrm{T}}>0.5$ and $X_{p}>X_{h}$ (i.e. inhibited reaction centres with more light absorbing than heat dissipating pigment) then $\Phi=1$, and the rate of switching is independent of the present mix of heat and light absorbing pigment. Otherwise, a parabolic form for $\Phi$ is used to reduce the rate of switching as the processes completes:

$$
\Phi=1-4\left(\frac{X_{p}}{X_{p}+X_{h}}-0.5\right)^{2}
$$

The parabola is at a maximum at $X_{p}=X_{h}$, but decreases by the square of the difference between the fraction of diadinoxanthin $\left(X_{p}\right)$ and 0.5. The square ensures that the fractional term does not change the overall sign of the switching, which, as already mentioned, is set by the reaction centre status (i.e. $\left.8\left(Q_{i n} / Q_{\mathrm{T}}-0.5\right)^{3}\right)$. The value of the parabolic term is zero at $X_{p}=$ $X_{h}$. At $X_{p}>>X_{h}$, or $X_{p}<<X_{h}$, the parabolic term is equal to 0.25 . The parabolic term is multiplied by 4 so that when switching is complete, $\phi=$ $1-1=0$, thus preventing $X_{p}$ or $X_{h}$ either exceeding $X_{p}+X_{h}$, or becoming negative. In summary the full switching term (Eq. 14) results in the relatively quick switching of the xanthophyll pigments between light absorbing and heat dissipating based on the oxidation status of the reaction centres.

The processes of light absorption by diadinoxanthin, chlorophyll $a$, chlorophyll $c_{2}$, peridinin and $\beta$-carotene is called photochemical quenching (PQ), 
while light absorbed and dissipated by diatoxanthin $\left(X_{h}\right)$ is called non-photochemical quenching (NPQ). A common measure of PQ is (1-Fv/Fm) (Raven, 1997), where $\mathrm{Fv}_{\mathrm{V}}$ is the difference between maximum fluorescence, Fm, and minimum fluorescence (i.e. variable fluorescence). Fv/Fm is a measurable ratio that represents the maximum potential quantum efficiency of Photosystem II if all capable reaction centres are open, which is equivalent in this model to $Q_{o x} / Q_{\mathrm{T}}$

\subsubsection{Carbon fixation / respiration}

When photons are captured by oxidised reaction centres (photosynthesis) there an increase in the cellular reserves of carbon, $R_{C}$, and an accompanying uptake of dissolved inorganic carbon, $\frac{106}{1060} 12 k_{I}\left(Q_{o x} / Q_{\mathrm{T}}\right) a_{Q_{o x}}^{*}\left(1-R_{C}^{*}\right)$, and release of oxygen per cell, $\frac{138}{1060} 32 k_{I}\left(Q_{o x} / Q_{\mathrm{T}}\right) a_{Q_{o x}}^{*}\left(1-R_{C}^{*}\right)$, to the water column (Table A.3). While the reserves of nutrients have been defined generically above (a quantity of $\mathrm{N}, \mathrm{P}$ taken up but not yet combined at the Redfield ratio), the reserves of carbon are a generic photosynthate - they represent the point at which a photon has been absorbed AND its energy used to produce fixed carbon and release oxygen.

Basal respiration represents a constant cost of cell maintenance. The loss of internal reserves, $\mu_{C S}^{\max } m_{C} \phi R_{C}^{*}$, results in a gain of water column dissolved inorganic carbon per cell, $\frac{106}{1060} \frac{12}{14} \mu_{C S}^{\max } \phi R_{C}^{*}$, as well as a loss in water column dissolved oxygen per cell, $\frac{138}{1060} \frac{32}{14} \mu_{C S}^{\max } \phi R_{C}^{*}$ (Table A.3). The loss in water column dissolved oxygen per cell represents an instantaneous respiration of the fixed carbon of the reserves. Basal respiration decreases internal reserves, and therefore growth rate, but does not directly lead to cell mortality at zero carbon reserves. Implicit in this scheme is that the basal cost is higher when the 
cell has more carbon reserves, $R_{C}^{*}$. A linear mortality term, resulting in the loss of structural material and carbon reserves, is considered below.

\subsection{Photosynthesis, reaction centre dynamics and reactive oxygen production}

To model the processes of photoinhibition we include a submodel of reaction centre dynamics that captures the fate of photons absorbed by the cell as a changing oxidation state of the reaction centre of photosystem II (PSII). The model contains state variables for the concentration of oxidised reaction centre, $Q_{\text {ox }}$, reduced reaction centre concentration, $Q_{\text {red }}$, and inhibited reaction centre concentration, $Q_{\text {in }}$, as well as the concentration of reactive oxygen species, [ROS] (Fig. 4). The reaction centre dynamics is based on stoichiometric relationships between reaction centre numbers, photons absorbed and the rate of generation of reactive oxygen species.

To follow the path of a photon as it moves through the reaction centres (Fig. 4), photons are absorbed by either a photosynthetic pigment, or a heat dissipating pigment, in the ratio of the concentration of the two pigment types. If the photon is absorbed by a heat dissipating pigment it is lost. If the photon is absorbed by a photosynthetic pigment, then it will result in a change in either the internal reserves of carbon, the reaction centre state, or the concentration of reactive oxygen species. Like absorption by pigments, the photons interact with the reaction centres as a proportion of the total number of reaction centres. If the photon encounters an oxidised reaction centre, the reserves are deplete and the Rubisco enzyme active, then the only change will be an increase in carbon reserves (i.e. carbon fixation). If the photon encounters an oxidised reaction centre, but fixation is inhibited, then an oxidised reaction 
centre becomes reduced. If the photon hits a reduced reaction centre, then a reduced reaction centre becomes inhibited. The final alternative, if the photon interactions with an inhibited reaction centre, then the reaction centre remains inhibited, and a reactive oxygen species is generated, adding to the reactive oxygen pool. The following sections derives rates for these pathways.

\subsubsection{Light absorption and photoinhibition}

The total rate of photon absorption due to photosynthetic pigments (chlorophyll $a$, chlorophyll $c_{2}$, peridinin, $\beta$-carotene and diadinoxanthin) across all wavelengths, $\lambda$, is given by:

$$
k_{I}=\frac{\left(10^{9} h c\right)^{-1}}{A_{V}} \int \alpha_{\lambda} E_{d, \lambda} \lambda d \lambda
$$

where $h, c$ and $A_{V}$ are fundamental constants (Table A.7). The absorptioncross section $(\alpha)$ of a spherical cell of radius $(r)$, with a wavelength-dependent pigment-specific absorption coefficient of chlorophyll and accessory pigments $\left(\gamma_{c h l+}\right)$ and diadinoxanthin $\left(\gamma_{d i a}\right)$, and homogeneous intracellular pigment concentration $\left(c_{i}\right.$ and $x_{p}$ respectively), can be calculated using geometric optics (i.e. ray tracing) without considering internal scattering, and is given by (Duysens, 1956; Kirk, 1975):

$$
\alpha=\pi r^{2}\left(1-\frac{2\left(1-\left(1+2\left(\gamma_{c h l+} c_{i}+\gamma_{d i a} x_{p}\right) r\right) e^{-2\left(\gamma_{c h l+} c_{i}+\gamma_{d i a} x_{p}\right) r}\right)}{\left(2\left(\gamma_{c h l+} c_{i}+\gamma_{d i a} x_{p}\right) r\right)^{2}}\right)
$$

where $\pi r^{2}$ is the projected area of the spherical zooxanthellae, and the bracketed term is 0 for no absorption $\left(\left(\gamma_{c h l} c_{i}+\gamma_{d i a} x_{p}\right) r=0\right)$ and approaches 1 as the cell becomes fully opaque $\left(\left(\gamma_{c h l} c_{i}+\gamma_{\text {dia }} x_{p}\right) r \rightarrow \infty\right)$. The pigment-specific absorption coefficient of chlorophyll and accessory pigments $\left(\gamma_{c h l+}\right.$, Fig. 5 black 
441

444

line) is given by:

$$
\gamma_{c h l+}=\gamma_{c h l a}+\Theta_{\text {chla2chlc }} \gamma_{c h l_{c}}+\Theta_{\text {chla2per }} \gamma_{\text {per }}+\Theta_{\text {chla2caro }} \gamma_{c a r}
$$

The component of light absorbed by oxidised reaction centres, and therefore available for carbon fixation, is:

$$
k_{I, f i x}=k_{I}\left(\frac{Q_{\mathrm{ox}}}{Q_{\mathrm{T}}}\right) a_{Q_{o x}}^{*}\left(1-R_{C}^{*}\right)
$$

where the oxidised fraction of reaction centres is $\left(Q_{\mathrm{ox}} / Q_{\mathrm{T}}\right)$ and the fixation rate can be limited by the carbon reserves $\left(1-R_{C}^{*}\right)$. If the carbon reserves are full ( $R_{C}^{*}$ approaches 1$)$ then fixation does not consume photons.

Carbon fixation is also reduced by the temperature inhibition of the active component of the reaction centres. This is the key term in coral bleaching. The mechanism through which this occurs is understood to be the inactivation of the Ribulose-1,5-bisphosphate carboxylase/oxygenase (RuBisCO, Lilley et al. (2010)). Field observations show bleaching occurs relative to the climatological value for each reef site (Liu et al., 2014), suggesting a mechanism for corals to adapt to local conditions. For practical purposes, we propose the following equation for the temperature-dependent inhibition of carbon fixation:

$$
a_{Q_{o x}}^{*}=(1-\exp (-(2-\Delta T))) /(1-\exp (-2))
$$

\footnotetext{
where $\Delta T$ is the temperature anomaly and is calculated as the difference between the model bottom temperature and the spatially and temporallyvarying climatological temperature at that depth (Ridgway and Dunn, 2003). The form of Eq. 20 was based on a general line of reasoning that bleaching stress begins at a temperature anomaly of $1^{\circ} \mathrm{C}$ (the NOAA bleaching index uses $1^{\circ} \mathrm{C}$ above climatology that would reduce $a_{Q_{o x}}^{*}$ in Eq. 20 to 0.73 ), and
} 
that for a sustained period ( 2 summer months) $2^{\circ} \mathrm{C}$ (equivalent to 16 degree heating weeks) causes maximal stress $\left(a_{Q_{o x}}^{*}=0\right)$. If the climatological temperature is below $26^{\circ} \mathrm{C}$, then $\Delta T$ is given by the model bottom temperature minus $26^{\circ} \mathrm{C}$. The constant $2^{\circ} \mathrm{C}$ represents the temperature anomaly above which activity of oxidised reaction centres is zero. For $\Delta T<0^{\circ} \mathrm{C}, a_{Q_{o x}}^{*}=1$, and all oxidised reaction centres are active, and $\Delta T>2^{\circ} \mathrm{C}, a_{Q_{o x}}^{*}=0$, and all oxidised reaction centres are inactive. Both the constant $2^{\circ} \mathrm{C}$, and the use of a seasonally-varying seabed climatological temperature which is based on all available, but nonetheless limited, number of in situ observations and interpolated onto a coarse $0.5^{\circ}$ grid, are key uncertainties worth consideration in future work.

The component of total absorption that is absorbed by oxidised reaction centres but not used in fixation and therefore responsible for moving reaction centres from an oxidised to reduced state is the remaining light absorbed at the oxidised centres:

$$
k_{I, \text { unfix }}=k_{I}\left(\frac{Q_{\mathrm{ox}}}{Q_{\mathrm{T}}}\right)-k_{I, f i x}
$$

Photons are absorbed by the reaction centres in each of the three oxidation states in proportion to the fraction in each state, independent of the carbon reserves. Absorption of a photon by an oxidised state is discussed above. Absorption by a reduced state moves it to an inhibited state. Absorption by an inhibited state does not change the state but produces ROS (see below):

$$
\begin{aligned}
& \frac{\partial Q_{\mathrm{ox}}}{\partial t}=-k_{I} n m_{\mathrm{RCII}} \frac{Q_{\mathrm{ox}}}{Q_{\mathrm{T}}}\left(1-a_{Q_{o x}}^{*}\left(1-R_{C}^{*}\right)\right) \\
& \frac{\partial Q_{\mathrm{red}}}{\partial t}=k_{I} n m_{\mathrm{RCII}} \frac{Q_{\mathrm{ox}}}{Q_{\mathrm{T}}}\left(1-a_{Q_{o x}}^{*}\left(1-R_{C}^{*}\right)\right)-k_{I} n m_{\mathrm{RCII}} \frac{Q_{\mathrm{red}}}{Q_{\mathrm{T}}}
\end{aligned}
$$




$$
\frac{\partial Q_{\mathrm{in}}}{\partial t}=k_{I} n m_{\mathrm{RCII}} \frac{Q_{\mathrm{red}}}{Q_{\mathrm{T}}}
$$

${ }_{502} \quad \frac{\partial[\mathrm{ROS}]}{\partial t}=32 \frac{138}{106} \frac{1}{10} k_{I} n m_{\mathrm{RCII}}\left(\frac{Q_{\text {in }}}{Q_{\mathrm{T}}}\right)$

503 where the stoichiometric conversions are $32 \mathrm{~g} \mathrm{O} \mathrm{mol} \mathrm{O}_{2}^{-1}, \frac{138}{106} \mathrm{~mol} \mathrm{O} \mathrm{mol} \mathrm{C}^{-1}$

$504 \frac{1}{10}$ mol C mol photon ${ }^{-1}$. Reactive oxygen species are not considered part of 
the oxygen mass balance, as it is assumed to be sourced and returned to the mass of water $\left(\mathrm{H}_{2} \mathrm{O}\right)$.

\subsubsection{Repair rate of inhibited reaction centres}

The repair rate of inhibited reactions centres is difficult to quantify, and may be a function of temperature (Hill et al., 2011). We took the assumption that the reaction centres would need to be able to repair damaged caused by $10 \mathrm{~mol}$ photon $\mathrm{m}^{-2} \mathrm{~d}^{-1}$. This relatively low daily averaged light intensity represents a threshold below which surface-adapted coral species show an impact due to low light, and might therefore be a reasonable minimum repair rate. As discussed later, this is one of the most uncertain components of the model.

To repair damaged caused by $10 \mathrm{~mol}$ photon $\mathrm{m}^{-2} \mathrm{~d}^{-1}$,

$$
\frac{\partial Q_{\text {in }}}{\partial t}=-268 m_{R C I I} Q_{\text {in }}=-\frac{\partial Q_{\mathrm{ox}}}{\partial t}
$$

where $m_{R C I I}$ is a stoichiometric coefficient [mol photon (mol reaction centre $)^{-1}$, and the constant 268 arises from the 10 mol photon $\mathrm{m}^{-2} \mathrm{~d}^{-1}$ limit.

\subsubsection{Rate of detoxification of reactive oxygen species}

Reactive oxygen species are reduced through a temperature-dependent processes (Hill et al., 2011):

$$
\frac{\partial[\mathrm{ROS}]}{\partial t}=-f(T) R_{N}^{*} R_{P}^{*} R_{C}^{*}[\mathrm{ROS}]
$$

where $f(T)$ is a function of temperature, and here is set at the maximum growth rate of the zooxanthellae cells. This particularly uncertain assumption results in the cells detoxifying at the same rate as they grow. The logic for 
this term is as simple as a healthier symbiont is one that grows faster, and coincidently, would have more resources for detoxification.

\subsection{Zooxanthellae expulsion}

The rate of expulsion of zooxanthellae cells is function of the reactive oxygen concentration, [ROS]:

$$
\frac{\partial C S}{\partial t}=-\max \left[\gamma, \frac{[\mathrm{ROS}]-\left[\mathrm{ROS}_{\text {threshold }}\right]}{m_{O}}\right] C S
$$

where $\gamma$ is the maximum expulsion rate, $m_{O}=(138 / 16)(32 / 14) m_{N}$ is the stoichiometric coefficient for the oxygen content of the structural component a cell, and $\left[\mathrm{ROS}_{\text {threshold }}\right]$ is the limit below which no bleaching occurs. A similar rate of loss is applied to $Q_{\mathrm{ox}}, Q_{\mathrm{red}}, Q_{\mathrm{in}}, C, X_{p}, X_{h}, R_{C}, R_{N}, R_{P}$ and [ROS]. Expulsion leads to an increase in detritus at the Redfield ratio, $D_{R e d}$, in the bottom water column layer from the zooxanthellae structural material, and an increased in dissolved nutrients (carbon, $D I C$, nitrogen in the form of ammonia $\left[\mathrm{NH}_{4}\right]$, and phosphorus, $P$ ) due to the loss of reserves (Table A.6).

\subsection{Description of the eReefs coupled hydrodynamic - biogeochemical model}

The eReefs model (Fig. 6) configuration used simulates the circulation, optics, biogeochemistry and sediment dynamics from December 1, 2014 - present. More details on the model grid and hydrodynamic configuration are given in Herzfeld and Gillibrand (2015) and Herzfeld (2015). The sediment (Margvelashvili et al., 2016), optical (Baird et al., 2016b) and biogeochemical (Mongin et al., 2016) models are similarly described in detail, with a further $600+$ pages 
Skerratt et al., submitted).

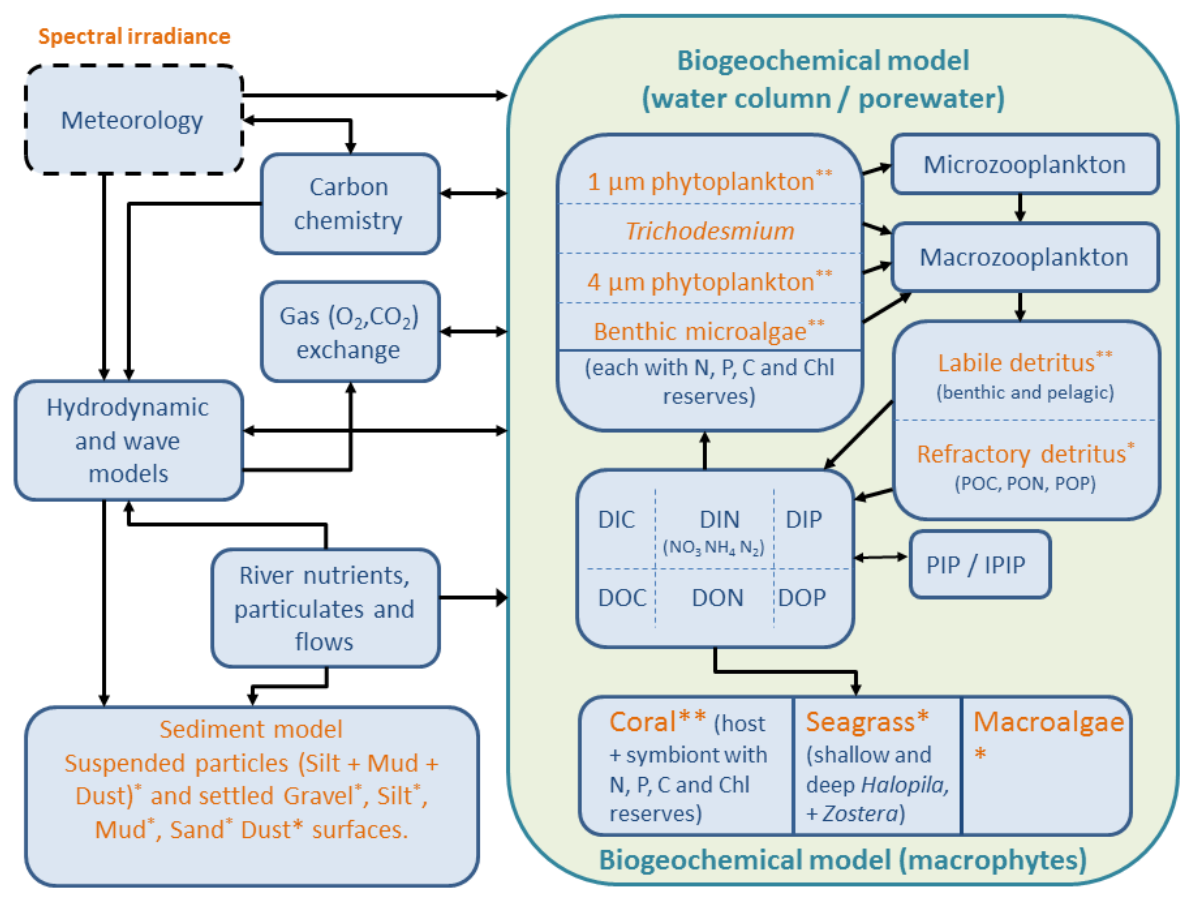

Fig. 6. Schematic showing the eReefs coupled hydrodynamic, sediment, optical, biogeochemical model. Orange labels represent components that either scatter or absorb light, thus influencing seabed light levels.

GBR-wide configuration. The eReefs coupled hydrodynamic, optical, sediment and biogeochemical model has been configured at $\sim 1 \mathrm{~km}$ resolution for the northeast Australian continental shelf, from $28^{\circ} 40^{\prime}$ S to the Papua New Guinea coastline. The model's curvilinear grid has 2389 cells in the alongshore direction, 510 in the offshore direction, and 44 depth levels. The hydrodynamic model is run with a $1.2 \mathrm{~s}$ barotropic time step, and the current fields used to calculate mass conserving fluxes of sediment and biogeochemical constituents (Gillibrand and Herzfeld, 2016). The sediment and biological processes are integrated using a 1 hour timestep.

A 5th-order Dormand-Prince ordinary differential equation integrator (Dormand. and Prince, 1980) with adaptive step control is used to integrate the 
local rates of changes due to ecological processes. This requires 7 function evaluations for the first step and 6 for each step after. A tolerance of $1 \times 10^{-5}$ $\mathrm{mg} \mathrm{N} \mathrm{m}^{-3}$ is required for the integration step to be accepted. The mass of carbon, nitrogen, phosphorus and oxygen are checked at each model timestep to ensure conservation.

The model is forced using atmospheric conditions from the Bureau of Meteorology ACCESS-R and OceanMaps atmospheric and ocean products, and concentrations of dissolved and particulate constituents from 21 rivers along the Queensland coast (north to south: Normanby, Daintree, Barron, combined Mulgrave+Russell, Johnstone, Tully, Herbert, Haughton, Burdekin, Don, O’Connell, Pioneer, Fitzroy, Burnett, Mary, Calliope, Boyne, Caboolture, Pine, combined Brisbane+Bremer, and combined Logan+Albert) and the Fly River in Papua New Guinea. River concentrations of sediment and nutrient were based on mean values from observations over a 10 year period (Furnas, 2003). Separate means were obtained for wet- (the Fly, and the northern most 6 rivers in Queensland) and dry- (remainder) catchment rivers, and multiplied by guaged flows to obtain river loads. The model uses a novel river boundary condition (Herzfeld, 2015) that discharges the river freshwater load in a brackish surface plume whose salinity and thickness is calculated to account for upstream flow in the salt wedge and in-estuary mixing between density layers. The coral distribution in the model is a combination of the eAtlas features map, or, where available, a satellite-derived coral zonation (Roelfsema et al., 2018).

Davies Reef configuration. The $\sim 200$ m model of Davies Reef off Townsville (centred on $18^{\circ} 49^{\prime}$ S, $147^{\circ} 38^{\prime}$ E, Andrews and Gentien (1982)) was built using the eReefs Project RECOM automatic nesting capability (https://research.csiro.au/ereef s/m The model bathymetry was interpolated from the GBR100 bathymetry (Bea- 
man, 2010) version 4 with improved resolution of reef tops. Atmospheric forcing was the same as the $1 \mathrm{~km}$ model above. The initial conditions of water column state variables are interpolated from a previous run of the $1 \mathrm{~km}$ model (GBR1_H2p0_B1p9_Chyd_Dhnd), while some benthic variables (seagrass and coral distributions) have distributions re-interpolated from the high resolution benthic maps, and assigned values from the nearest neighbour in the initialising model.

The $\sim 200$ m nested model uses boundary conditions provided by a standard eReefs $1 \mathrm{~km}$ model simulation (GBR1_H2p0_B1p9_Chyd_Dhnd) that did not include coral bleaching. Thus the model that generated the boundary conditions for the nested model is slightly different to the $1 \mathrm{~km}$ configuration described above, but the water column properties that are advected into the nested model, which depend primarily on nutrient / plankton processes in the water column, will be very similar. The boundary condition for all water column tracers was formulated using the advection scheme (Van Leer, 1977) used within the model domain itself. This consistency of boundary and advection schemes ensures diffusion and dispersion errors are minimised.

\section{Results}

The coral bleaching model presented in this paper details new formulations for the processes of zooxanthellae growth as a function of the interaction of nutrient and light uptake; photoadaption through the pigment synthesis and xanthophyll cycling; photoinhibition through reaction centre dynamics; and zooxanthellae expulsion through a build-up of reactive oxygen species. Here we describe the model behaviour in a $\sim 1 \mathrm{~km}$ configuration along the entire 
Great Barrier Reef during a mass bleaching event in early 2016; in a 200 m nested model of Davies Reef; and finally, at the scale of one polyp through analysing a time-series at two depths in the Davies Reef model.

\subsection{GBR-scale behaviour of the zooxanthellae model}

The 2016 bleaching event was the most severe experienced by the Great Barrier Reef, with the greatest bleaching occurring in the far north (Hughes et al., 2017). This extreme event provides a good test of the model. On January 1 , the simulated water temperature at the coral surface was only just above the summer monthly maximum, as shown by the simulated RuBisCO activity being close to 1 (i.e. not inhibited by thermal stress) (Fig. 7, left). By February 1 the temperature relative to climatology had increased significantly, and did not reduce until after April 1.

The response in concentration of reactive oxygen on January 1 (Fig. 8) shows zooxanthellae on some shallow reefs had relatively high levels of oxidative stress. By February 1, most of the reefs north of Hinchinbook Island shows high levels of reactive oxygen, although interestingly this reduced somewhat by March 1 . The model predicted reactive oxygen stress has a similar spatial distribution as the observed bleaching from aerial surveys (Fig. 8, bottom left) with the exception that the model bathymetry is too deep at most of the offshore reefs to accumulate oxidative stress. While these results are promising, they illustrate that for the purposes of predicting coral bleaching, the $\sim 1 \mathrm{~km}$ model suffers from poor resolution of many of the outer-reef reef tops. 


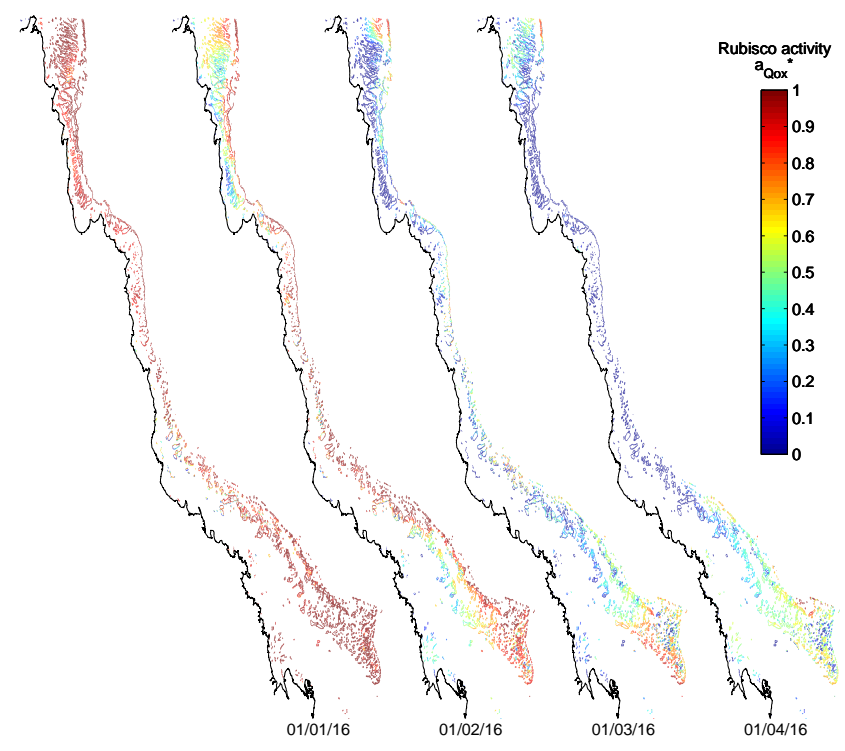

Fig. 7. Activity of the RuBisCO enzyme, $a_{Q_{o x}}^{*}$ (Eq. 20), from left to right, at midday on the 1st of January, February, March and April of 2016 based on simulated seabed temperature. A value of $a_{Q_{o x}}^{*}=1$ allows full use of photons absorbed by oxidised reaction centres to fix carbon, thereby quenching photons and filling carbon reserves (Fig. 4). For a value of zero, a result of being greater than $2^{\circ} \mathrm{C}$ above the climatology, all photons move oxidised and / or reduced reaction centres towards the inhibited state.

\subsection{Individual (Davies) reef scale behaviour}

Davies Reef is a $4 \mathrm{~km} \times 2 \mathrm{~km}$ kidney-shaped reef located off Townsville (Fig. 9). In the $\sim 1 \mathrm{~km}$ model described above Davies consists of approximately 8 grid cells with a minimum depth of $15 \mathrm{~m}$ below mean sea level. In the $\sim 200$ m nested model, which can resolve reef tops far better, the minimum depth is $3.8 \mathrm{~m}$. This allows for a much greater spatial variation in light at the seabed (Fig. 9, photosynthetically available radiation, PAR). Other environmental variables such as temperature, DIN, DIP, and particulate organic matter (POM) also show variation across the reef as the fast-moving overlying 


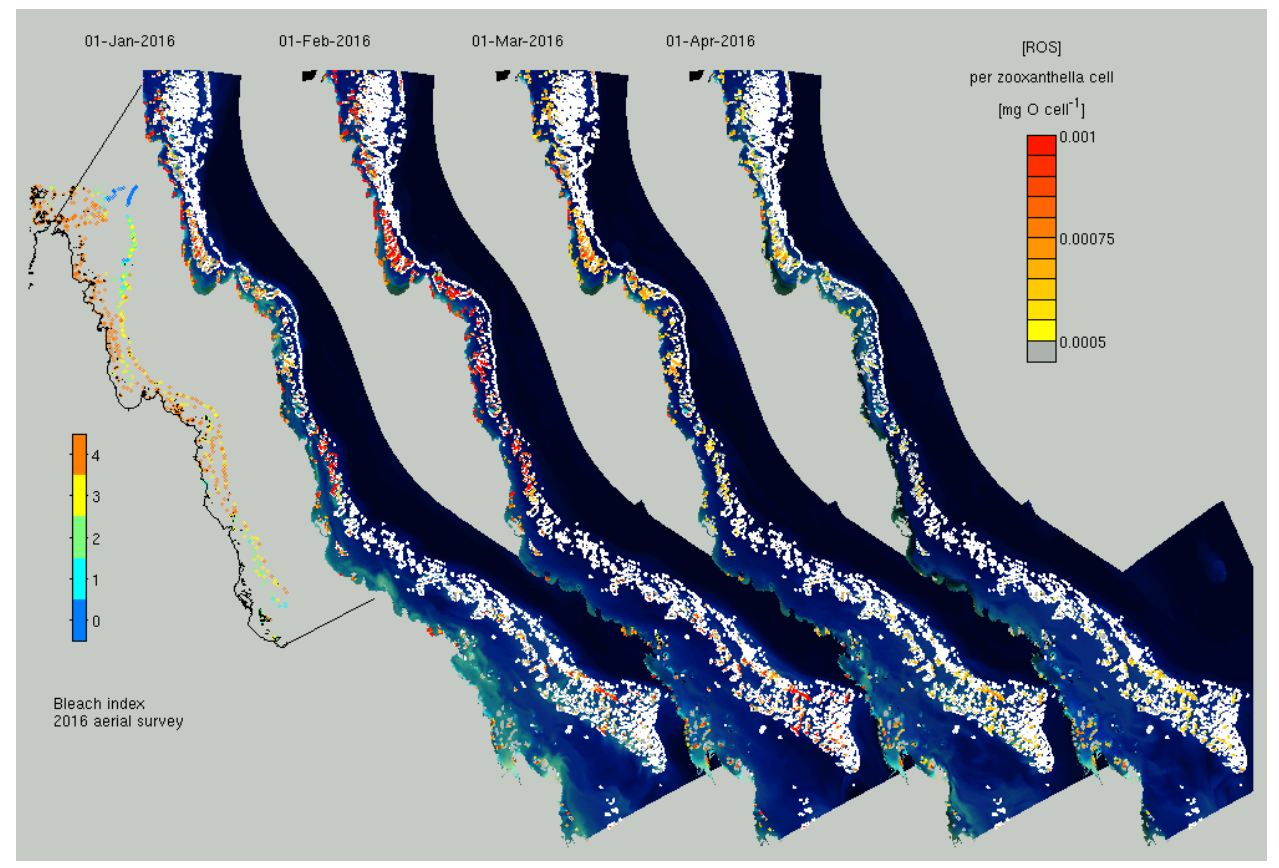

Fig. 8. Snapshots of reactive oxygen accumulation per zooxanthellae cell in the $1 \mathrm{~km}$ eReefs model, from left to right, on the 1st of January, February, March and April of 2016, and compared to the aerial bleaching surveys conducted in March-April 2016 (left, Hughes et al. (2017)). The background water colour is the model output simulated true colour (Baird et al., 2016b), and can be used as an indicator of water clarity between reefs on the day. Reefs $\left(\sim 1 \mathrm{~km}^{2}\right.$ in the model $)$ are coloured white if deeper than $20 \mathrm{~m}$, to indicate they are too deep to bleach in the model; grey if they are sufficiently shallow to potentially bleach, but have reactive oxygen concentrations below $\left[\mathrm{ROS}_{\text {threshold }}\right]$, and yellow through to red to indicate increasing reactive oxygen stress. The ARC Centre of Excellence National Bleaching Taskforce bleach index scales from 0 ( $<1 \%$ of colonies bleached), 1 (1-10\%), 2 (10-30\%), 3 $(30-60 \%)$ and $4(60-100 \%)$. Two thin black lines show the extent of the Bleaching Survey on the model domain. The reactive oxygen concentration per zooxanthella and bleaching index can be qualitatively compared, but a quantitative comparison would rely on uncertain components of the model.

waters are altered by fluxes with the benthos.

Focusing on the diurnal change, at 6 am, all xanthophyll pigments are photoabsorbing, and the reaction centres are primarily oxidised (Fig. 9). The nitrogen assimilation by corals is dominated by organic nitrogen uptake (i.e. heterotrophic feeding), which in the model is only allowed in dark conditions. By 3 pm, most xanthophyll pigments have switched to heat dissipating, with the exception of those below $20 \mathrm{~m}$ that remain photoabsorbing. The reaction 
centres in shallow waters have become strongly inhibited, although again at depth remain primarily oxidised. Interestingly, the reserves of $\mathrm{C}, \mathrm{N}$, and $\mathrm{P}$, as well as the reactive oxygen concentration, remain relatively constant through the day. This is because the growth of zooxanthellae is relatively slow, so the reserves are not being depleted quickly.

As the reactive oxygen concentration is relatively constant, the bleaching rate is only moderately stronger during the day. Bleaching is occurring only in waters less than $10 \mathrm{~m}$. The temperature-mediated inactivity of RuBisCO, $a_{Q_{o x} *}$, is more evenly spread across the reef - thus the reduced bleaching below $10 \mathrm{~m}$ is due to lower light levels rather than less thermal stress. 


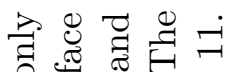

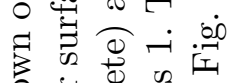

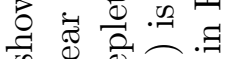

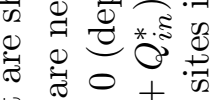
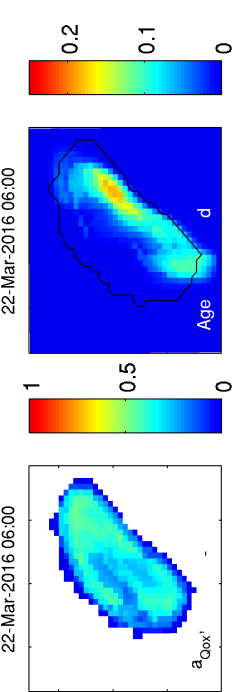

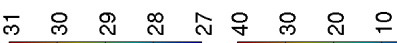
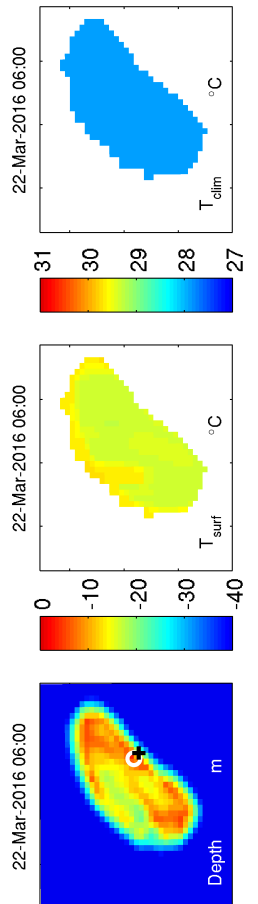

응ㅇㅇ웅

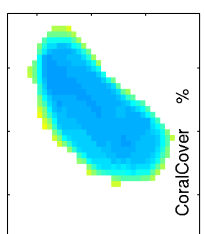

0
$\infty$
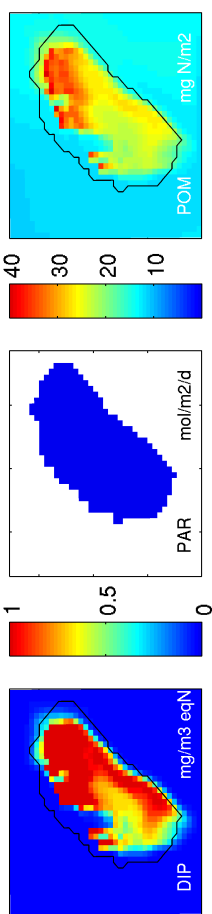

น?

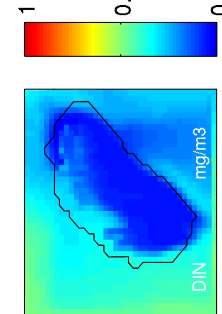

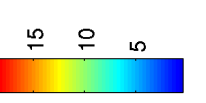
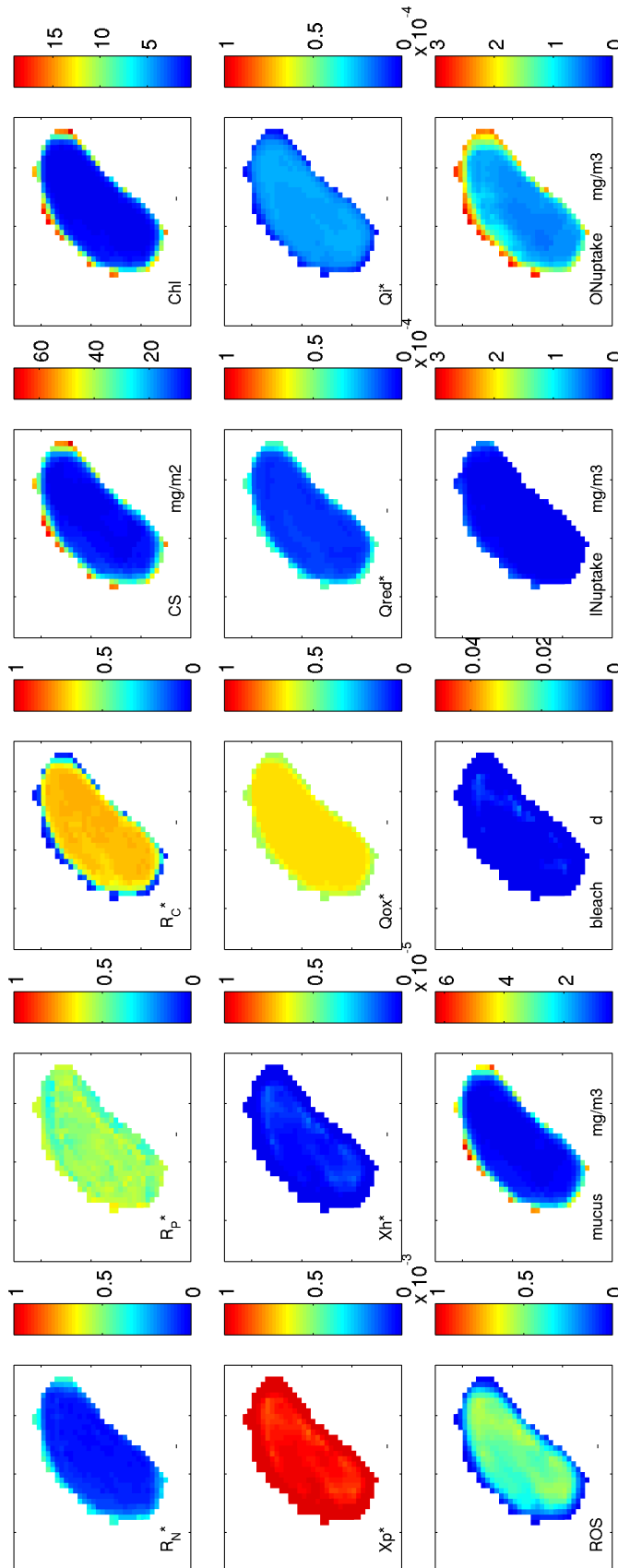
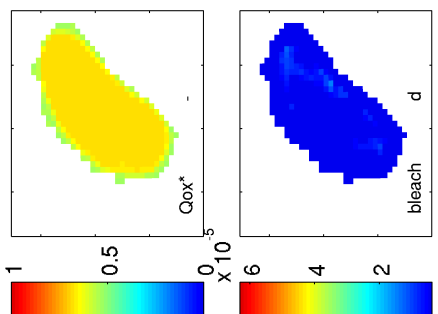

(a)
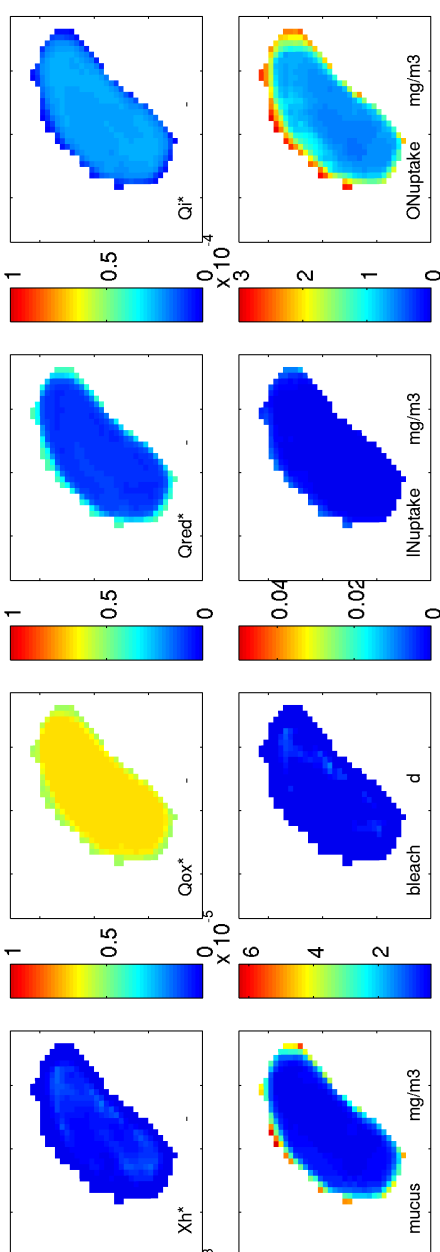

웅

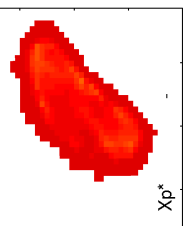

烏

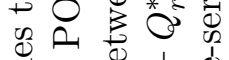
궁 0

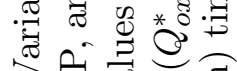

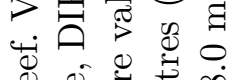

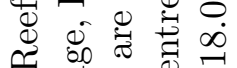
《 4 过

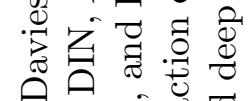

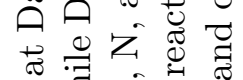
ठ

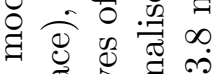
ठ 苟

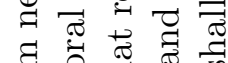
व 0 जे क 实过 र $\overrightarrow{0}+$ o \& 0 ० $\exists \approx \frac{1}{\pi}$

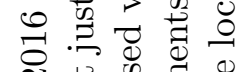
๙ 월 㞼

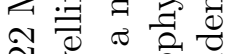
궁요용 ○ี द्व $0 \underbrace{0}_{0}$ ○. . 若 कै द त $\stackrel{0}{-\dot{1}} \dot{0}$

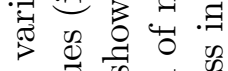

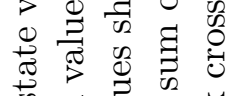

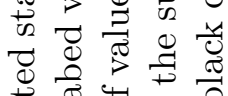
焉 i.

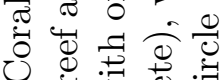
$\begin{array}{llll}0 & 0 & 0 & 0 \\ 0 & 0 & 0 \\ 0 & 0 & 0 & 0 \\ 0 & 0 & 0 & 0 \\ 0 & 0 & 0\end{array}$ 


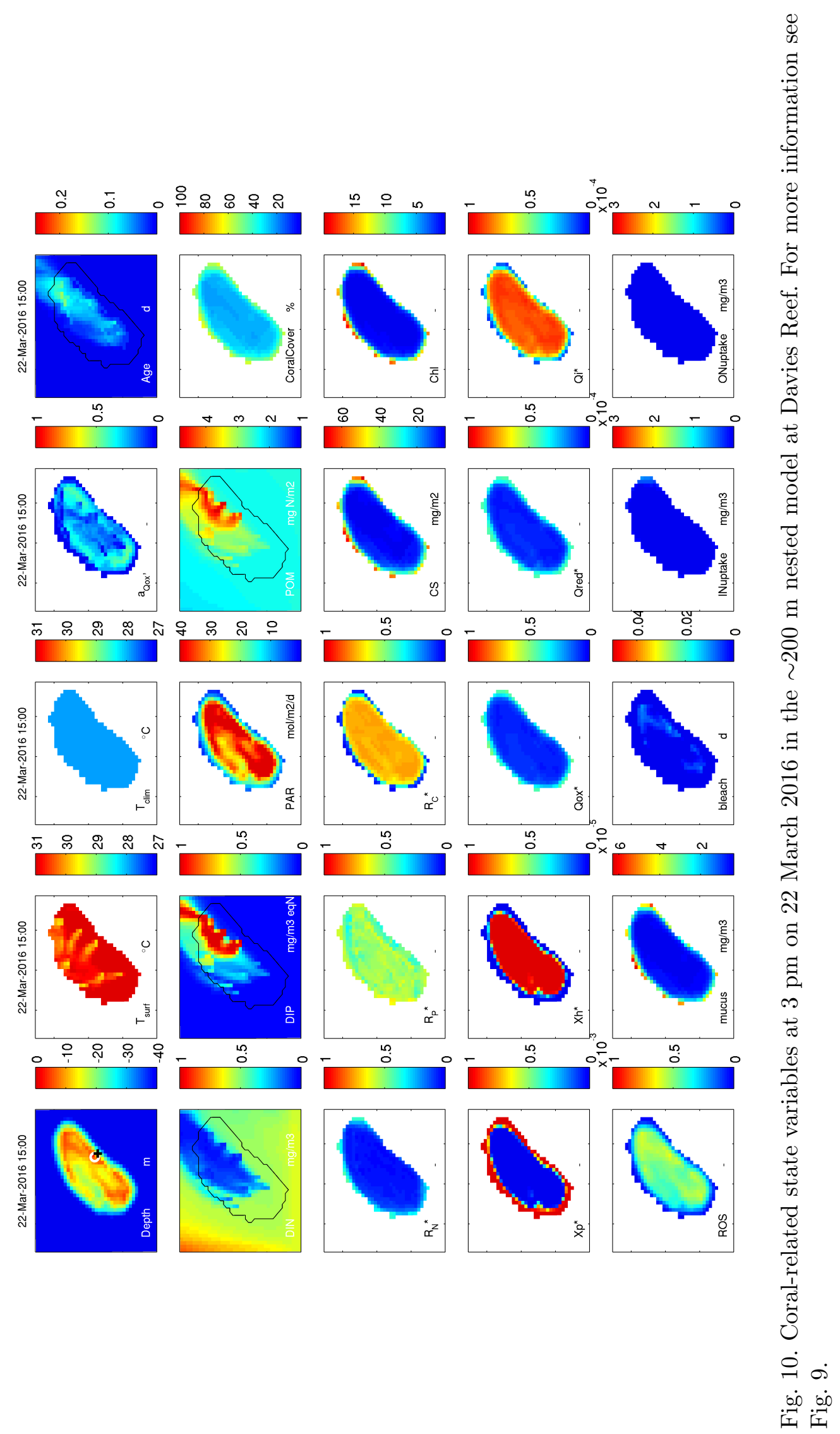




\subsection{Polyp-scale behaviour of the zooxanthellae model}

Analysis of time-series at two depths in the Davies Reef nested configuration can be used to further investigate the behaviour of the coral bleaching model. We have chosen two adjacent sites, one shallow and one deep (Fig. 9, depth panel). Here we are looking at the physiological response of the zooxanthellae photosystem to different light levels under thermal stress (Fig. 11).

\subsubsection{Zooxanthellae growth limitation}

Zooxanthellae growth is a function of the maximum growth rate, and the reserves of nitrogen, phosphorus and carbon. Each normalised reserve, $R^{*}$, is a value between zero and one. The normalised reserved increases when the supply of the nutrient exceeds the consumption for growth, and decreases when consumption for growth exceeds the nutrient supply (Baird et al., 2003). In coral reef environments, nutrients are generally strongly limiting in the surface waters, and less so at depth. One exception to this generality is if RuBisCO becomes inactive at high temperatures, and then absorption does not add to carbon reserves and growth can become limited by fixed carbon.

At the shallow site (Fig. 11A) carbon reserves are high ( 0.7), phosphorus reserves intermediate $(\sim 0.6)$, and nitrogen reserves low $(<0.1)$. Thus growth is strongly $\mathrm{N}$ limited. High carbon reserves can be maintained in part because RuBisCO is moderately active ( $a_{Q_{o x}}^{*} \sim 0.5$, Fig. 11B), although on the $3 \mathrm{rd}$ March the carbon reserves can be seen to drop when RuBisCO became inactive for 24 hours (Fig. 11B). At the deep site (Fig. 11D), we see that the carbon reserves are also high and the zooxanthellae are still nitrogen limited. This is possible because of the clear water (bottom light is only halved from the 3.8 
$m$ site), and because of photoacclimation described in next section.

\subsubsection{Zooxanthellae photoacclimation}

Photoacclimation occurs through changing rates of pigment synthesis and xanthophyll pigment switching.

Pigment synthesis. At the shallow site, the cells adjust to high light by reducing pigment synthesis resulting in a high C:Chl ratio of $\sim 100 \mathrm{~g} / \mathrm{g}$ (Fig. 11B). A high C:Chl ratio is a low cellular chlorophyll concentration. At the deep site, the $\mathrm{C}: \mathrm{Chl}$ is reduced to $\sim 40 \mathrm{~g} / \mathrm{g}$ as chlorophyll synthesis is greater to capture a higher percentage of the photons that are hitting the cells.

Xanthophyll cycle. At the shallow site the reaction centres are inactive during the day, with recovery over night (Fig. 11C). As a result, the xanthophyll cycle is primarily in the heat dissipating state during the day, and light absorbing in the early morning. In contrast at the deeper site (Fig. 11F), a greater fraction of the reaction centres are oxidised, and therefore the xanthophyll pigments are all in the photosynthesising state. The photoacclimation processes are able to keep the carbon reserves to a relatively similar level at the two sites despite light levels varying from 8 to $80 \mathrm{~mol}$ photon $\mathrm{m}^{-2} \mathrm{~d}^{-1}$. This is in part due to impact of nitrogen limitation on the other reserves.

\subsubsection{Reactive oxygen accumulation and bleaching.}

The rate of ROS build up depends on both the fraction of inhibited reaction centres, and the flux of photons to the reaction centres. Thus at the deep site the reactive oxygen concentration is low, and the bleaching rate is zero (Fig. 11F). In contrast, at the shallow site there was a substantial fraction 
of inactive reaction centres (Fig. 11C), and a large photon flux, so reactive oxygen concentration builds up. At the shallow site in early March, when RuBisCO became totally inactive, more photons hit inactive reaction centres, and there was an even greater accumulation of ROS, leading to more zooxanthellae expulsion (Fig. 11C).

\section{Discussion}

In this paper we have introduced new formulations of coral host-symbiont interactions, photoadaptation, xanthophyll cycling and reactive oxygen dynamics. Outputs of a simulation at the GBR-wide scale show promise for predicting mass bleaching events, and the behaviour at the scale of the Davies Reef appear reasonable. At this point in the model development, components of the model derivation are uncertain, and the laboratory and field data sets to assess the model outputs are still emerging. Nonetheless, this represents the first application of a sophisticated coral bleaching model applied across a entire shelf system.

\subsection{Model formulation}

The coral-symbiont model presented here is derived from process representations that take advantage, where possible, of geometric or physical constraints. The geometric descriptions used include: (1) a relationship between polyp biomass and coral cover derived from a random-placement geometric model (Eq. 2); (2) the limiting term for zooxanthellae self-shading based on the derivative of the absorption cross-section against absorption of the pigments 
(Eq. 12); (3) the uptake of dissolved nutrients through a diffusive boundary layer (Eq. 9); and (4) the space-limitation of zooxanthellae using zooxanthellae projected areas in a two layer gastrodermal cell anatomy (Eq. 10). One advantage of this geometric approach is that it often requires fewer and better constrained parameters than more empirical process descriptions. This approach has proven successful in other marine biogeochemical applications (Baird et al., 2004a; Wild-Allen et al., 2013), and is fundamental to the formulation of the eReefs biogeochemical model (Baird et al., 2016b).

The mathematical formulations also take advantage of stoichiometric relationships between reaction centre numbers, photons absorbed and the concentration of reactive oxygen species created. It is a unique characteristic of the eReefs biogeochemical water column optical model (Baird et al., 2016b) that the processes of absorption by photoautotrophs are photon conserving, such that the photosynthetic growth processes in phytoplankton and benthic plants are a function of stoichiometric combination of photons and nitrogen and phosphorus (Baird et al., 2001). This approach is also applied in zooxanthellae, with the absorption coefficient of the multiple pigments determining the number of photons absorbed, and then this quantity reduces reaction centres, or accumulates carbon or reactive oxygen, in stoichiometrically determined ratios. By using these constraints the model is able to resolve reaction centre state (Fig. 4), and include the processes of photoinhibition and reactive oxygen generation, with the inclusion of just a few new model parameters, such as the stoichiometric ratio of RCII units to photons, $m_{\mathrm{RCII}}$, and a few temperature-dependent reaction rates.

We openly recognise that we do not have the knowledge to follow all processes mechanistically. Thus, the inactivation of the RuBisCO-mediated carbon fix- 
ation (Eq. 20), the repair rate of inhibited reaction centres (Eq. 26), and the detoxification rate of reactive oxygen species (Eq. 27) are temperaturedependent empirical formulations, for which the underlying biochemical reactions are not resolved. Additionally, the reactive oxygen concentration that initiates bleaching, $R O S_{\text {threshold, }}$ and the mathematical form of the expulsion above this threshold (Eq. 28), are based on simple reasoning. Emerging laboratory techniques (Murphy et al., 2017) may provide the quantitative understanding necessary to formulate more mechanistic process descriptions.

The descriptions of ROS dynamics that are empirically formulated are the characteristics that would be considered unique for temperature tolerant corals (Bay et al., 2016), and thus those that may determine the resilience of reefs in the future (Matz et al., 2018). As these uncertainties are fundamental to some management strategies being considered (Anthony et al., 2017), it is urgent that modellers use the emerging understanding of the processes driving ROS toxicity as it becomes available.

There is also considerable uncertainty of the role of all pigments in the electron chain. Fujiki and Taguchi (2001) propose that the photosynthetic xanthophyll pigment diadinoxanthin does not pass photons onto chlorophyll $a$, while other works suggest photosynthetic xanthophylls do drive carbon fixation (Falkowski and Raven, 2007). In this paper we provide a path from diadinoxanthin absorption to carbon fixation (Fig. 4). Other detailed structural studies show that the morphology of the pigment bed changes with physiological status (Liu et al., 2004), thus potentially changing the roles of pigments. The challenge of including knowledge from detailed biochemical studies like these is formidable, and is not attempted here.

Even in the cases where physical constraints are used in the model for- 
mulation, there is uncertainty regarding their form. For example, the model presented here uses sphere packing geometry in a two layer gastrodermal cell anatomy to determine the translocation fraction of zooxanthellae growth (Eq.10). Another study (van Woesik et al., 2010), for example, considers layers of cells stacked vertically, with the light intensity of lower layers limiting zooxanthellae density. While it may be possible to choose the most appropriate mechanistic formulation for a particular coral species, the task of choosing a generic form, as we have attempted here, inevitably has shortcomings.

The model developed here does not consider all phenomena relevant to bleaching. For example, the model considers only one mechanism for thermal stress induced bleaching, while the existence of bleaching under low light conditions demonstrates that other mechanisms exist (Tolleter et al., 2013). Further only one generic coral type, and one Symbiodinium clade, is considered. Thus the simulation here is not able to resolve the differences between temperature tolerances of different corals assemblages (Bay et al., 2016).

Finally, the eReefs biogeochemical model (Baird et al., 2016b) that incorporates the new zooxanthellae photophysiological processes derived in this paper represents only a fraction of the processes affecting coral health. For example, the model represents only one coral type, and one macroalgae type, and considers the only interaction between the two is a competition for nutrients and light. A more sophisticated, ecosystem or habitat style model would consider multiple coral and seagrass types inhabiting particular niches on the seabed, and interacting with a range of herbivorous fish (Bozec et al., 2018). Such an improved representation of coral mortality, which could include other processes such as cyclone damage and starfish grazing (Babcock et al., 2016), would remove the need for the ad-hoc quadratic mortality term for coral hosts. 
Despite all the simplifications and omissions, the model developed here does represent a comprehensive set of processes spanning scales from the polyp processes to the shelf-scale, and from nutrient and photochemical interactions to coral symbiosis.

\subsection{Future applications}

The use of satellite-derived temperature exposure alone as a measure of coral bleaching severity has been broadly successful (Liu et al., 2014), and is used operationally at a global scale. Nonetheless, it has not captured all bleaching events accurately, and work is under way to include solar radiation in bleaching algorithms (Skirving et al., 2018). Even with additional considerations such as solar radiation, satellite algorithms will always be limited to the estimation of near-surface properties, and their inability to consider factors affecting bleaching such as dissolved nutrients (D'Angelo and Wiedenmann, 2014) that cannot be remotely-sensed. Furthermore satellite observations will never be predictive. Thus, the near real time prediction and forecasting of coral bleaching by a biogeochemical model such as developed here that can consider the history of temperature, light and other environmental conditions at the surface of the corals provides a means to overcome some of these limitations.

Finally, a process-based model is capable of explicitly representing management strategies such as local shading (Coelho et al., 2017), marine cloud brightening, or increased stress tolerance of individuals and/or populations of coral or zooxanthellae (Anthony et al., 2017). The eReefs modelling framework has already been used to optimise catchment management for the purposes of improving water quality on the Great Barrier Reef (Brodie et al., 2017). 
829 The bleaching model derived here will next be used to quantify the impact 830 of interventions designed to minimise the impacts of a warming ocean on the 831 corals of the Great Barrier Reef. 

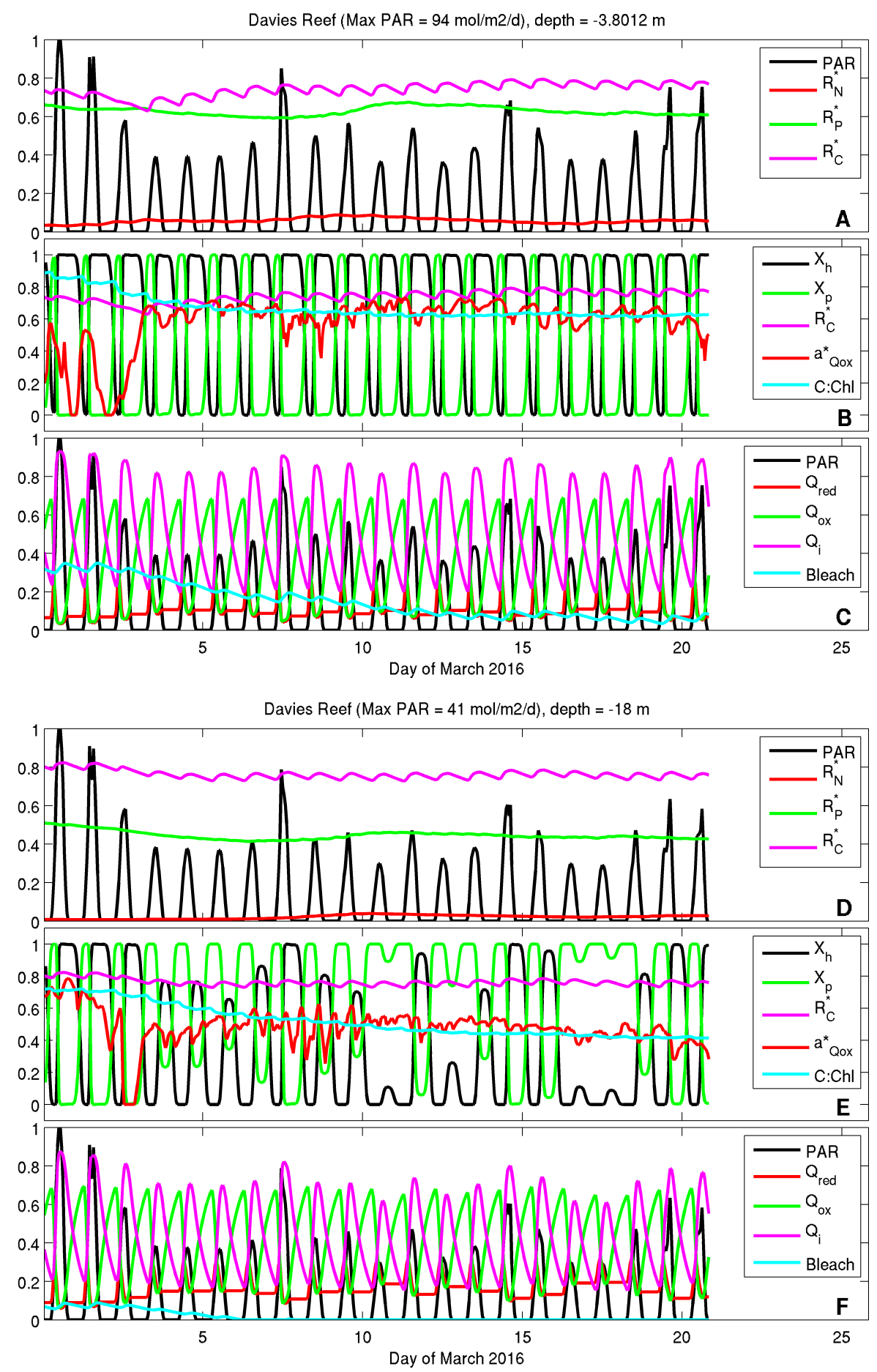

Fig. 11. Model behaviour at Davies Reef at a shallow (3.8 m, top 3 rows) and a deep (18.0 m, bottom three rows) site in March 2016. Panels A and D show the light at the coral surface (PAR, mol photon $\mathrm{m}^{-2} \mathrm{~d}^{-1}$, scaled on the $y$-axis to the maximum PAR given in the title), and the normalised reserves of nitrogen, phosphorus and carbon. Panels B and E show the state of the xanthophyll cycle as the fraction of heat absorbing $\left(X_{h}\right)$ and heat dissipating $\left(X_{p}\right)$ pigments, the RuBisCO activity $\left(a_{Q_{o x}}^{*}\right.$, varying between inactive at 0 and fully active at 1 ), and the carbon to chlorophyll ratio (scaled on the $y$-axis so the minimum C:Chl ratio of $20 \mathrm{~g} / \mathrm{g}$ is 0 , and 1 is $180 \mathrm{~g} / \mathrm{g}$ ). Panels $\mathrm{C}$ and $\mathrm{F}$ show the state of the reaction centres, and the rate of bleaching $\left(\times 10 \mathrm{~d}^{-1}\right)$. 


\section{Acknowledgements}

The coral bleaching model presented here was developed with funding from CSIRO and the National Environmental Science Programme (NESP) Tropical Water Quality Hub (Project No. 3.3.1). The model simulations were developed as part of the eReefs project, a public-private collaboration between Australia's leading operational and scientific research agencies, government, and corporate Australia. The authors wish to thank the many scientists involved in the project, in particular Mike Herzfeld, John Andrewatha, Nugzar Margvelashvili, Karen Wild-Allen, Barbara Robson, Andy Steven and Cedric Robillot. Observations used in the eReefs project include those from the Integrated Marine Observing System (IMOS) and the Marine Monitoring Program (MMP). ARC Centre of Excellence National Bleaching Taskforce survey data was download from http://dx.doi.org/10.1002/ecy.2092 (Hughes et al., 2017).

The authors appreciate fruitful discussions with Peter Ralph as the model was developed from the one-polyp model of Gustafsson et al. (2014) to the model described here. Lesley Clementson kindly provided the pigment-specific absorption coefficients from unpublished experiments conducted at the CSIRO Hobart Laboratories. This absorption data, and the entire model code used in this study, is available on request to the authors.

\section{References}

Andrews, J. C., Gentien, P., 1982. Upwelling as a source of nutrients for the Great Barrier Reef Ecosystems: A solution to Darwin's Question. Mar. Ecol. Prog. Ser. 8, 257-269.

Anthony, K., Bay, L. K., Costanza, R., Firn, J., Gunn, J., Harrison, P., Hey- 
ward, A., Lundgren, P., Mead, D., Moore, T., Mumby, P. J., van Oppen, M. J. J., Robertson, J., Runge, M. C., Suggett, D. J., Schaffelke, B., Wachenfeld, D., Walshe, T., 2017. New interventions are needed to save coral reefs. Nature Ecol. Evol. 1, 1420-1422.

Atkinson, M. J., Bilger, B. W., 1992. Effects of water velocity on phosphate uptake in coral reef-flat communities. Limnol. Oceanogr. 37, 273-279.

Babcock, R. C., Dambacher, J. M., Morello, E. B., Plagnyi, E. E., KR, K. R. H., Sweatman, H. P. A., 2016. Assessing different causes of Crown-ofThorns starfish outbreaks and appropriate responses for management on the Great Barrier Reef. PLoS ONE 11, e0169048.

Baird, M. E., Adams, M. P., Babcock, R. C., Oubelkheir, K., Mongin, M., Wild-Allen, K. A., Skerratt, J., Robson, B. J., Petrou, K., Ralph, P. J., O'Brien, K. R., Carter, A. B., Jarvis, J. C., Rasheed, M. A., 2016a. A biophysical representation of seagrass growth for application in a complex shallow-water biogeochemical model. Ecol. Model. 325, 13-27.

Baird, M. E., Cherukuru, N., Jones, E., Margvelashvili, N., Mongin, M., Oubelkheir, K., Ralph, P. J., Rizwi, F., Robson, B. J., Schroeder, T., Skerratt, J., Steven, A. D. L., Wild-Allen, K. A., 2016b. Remote-sensing reflectance and true colour produced by a coupled hydrodynamic, optical, sediment, biogeochemical model of the Great Barrier Reef, Australia: comparison with satellite data. Env. Model. Softw. 78, 79-96.

Baird, M. E., Emsley, S. M., McGlade, J. M., 2001. Modelling the interacting effects of nutrient uptake, light capture and temperature on phytoplankton growth. J. Plankton Res. 23, 829-840.

Baird, M. E., Oke, P. R., Suthers, I. M., Middleton, J. H., 2004a. A plankton population model with bio-mechanical descriptions of biological processes in an idealised 2-D ocean basin. J. Mar. Sys. 50, 199-222. 
Baird, M. E., Ralph, P. J., Rizwi, F., Wild-Allen, K. A., Steven, A. D. L., 2013. A dynamic model of the cellular carbon to chlorophyll ratio applied to a batch culture and a continental shelf ecosystem. Limnol. Oceanogr. 58, $1215-1226$.

Baird, M. E., Roughan, M., Brander, R. W., Middleton, J. H., Nippard, G. J., 2004b. Mass transfer limited nitrate uptake on a coral reef flat, Warraber Island, Torres Strait, Australia. Coral Reefs 23, 386-396.

Baird, M. E., Walker, S. J., Wallace, B. B., Webster, I. T., Parslow, J. S., 2003. The use of mechanistic descriptions of algal growth and zooplankton grazing in an estuarine eutrophication model. Est., Coastal and Shelf Sci. $56,685-695$.

Bay, L. K., Doyle, J., Logan, M., Berkelmans, R., 2016. Recovery from bleaching is mediated by threshold densities of background thermo-tolerant symbiont types in a reef-building coral. Royal Society Open Science 3, 160322.

Beaman, R. J., 2010. Project 3DGBR: A high-resolution depth model for the Great Barrier Reef and Coral Sea, pp. 13 plus Appendix 1. Tech. rep., Marine and Tropical Sciences Research Facility (MTSRF) Project 2.5i.1a Final Report, MTSRF, Cairns, Australia.

Beckmann, A., Hense, I., 2004. Torn between extremes: the ups and downs of phytoplankton. Ocean Dynamics 54, 581-592.

Bozec, Y.-M., Doropoulos, C., Roff, G., Mumby, P. J., Jun 2018. Transient grazing and the dynamics of an unanticipated coral-algal phase shift. Ecosystems.

Brodie, J., Baird, M., Mongin, M., Skerratt, J., Robillot, C., Waterhouse, J., 2017. Pollutant target setting for the Great Barrier Reef: Using the eReefs framework. In: Syme, G., Hatton MacDonald, D., Fulton, B. and Piantadosi, J. (eds), MODSIM2017, 22nd International Congress on Modelling 
and Simulation. Modelling and Simulation Society of Australia and New Zealand, December 2017. pp. 1913-1919.

Coelho, V. R., Fenner, D., Caruso, C., Bayles, B. R., Huang, Y., Birkeland, C., 2017. Shading as a mitigation tool for coral bleaching in three common Indo-Pacific species. J. Exp. Mar. Biol. Ecol. 497, 152-163.

Cunning, R., Muller, E. B., Gates, R. D., Nisbet, R. M., 2017. A dynamic bioenergetic model for coral-Symbiodinium symbioses and coral bleaching as an alternate stable state. J. Theor. Biol. 431, 49 - 62 .

D'Angelo, C., Wiedenmann, J., 2014. Impacts of nutrient enrichment on coral reefs: new perspectives and implications for coastal management and reef survival. Current Opinion in Environmental Sustainability 7, 82 - 93.

Dormand., J. R., Prince, P. J., 1980. A family of embedded Runge-Kutta formulae. J. Comp. App. Math. 6, 19-26.

Duysens, L. N. M., 1956. The flattening of the absorption spectra of suspensions as compared to that of solutions. Biochim. Biophys. Acta 19, 1-12.

Eynaud, Y., Nisbet, R. M., Muller, E. B., 2011. Impact of excess and harmful radiation on energy budgets in scleractinian corals. Ecological Modelling $222(7), 1315-1322$.

Falkowski, P. G., Raven, J. A., 2007. Aquatic Photosynthesis, 2nd Edition. Blackwell Science.

Falter, J. L., Atkinson, M. J., Merrifield, M. A., 2004. Mass-transfer limitation of nutrient uptake by a wave-dominated reef flat community. Limnol. Oceanogr. 49, 1820-1831.

Finkel, Z. V., 2001. Light absorption and size scaling of light-limited metabolism in marine diatoms. Limnol. Oceanogr. 46, 86-94.

Fujiki, T., Taguchi, S., 2001. Relationship between light absorption and the xanthophyll-cycle pigments in marine diatoms. Plankton Biol. Ecol. 48, 96- 
103.

Furnas, M., 2003. Catchments and corals: terrestrial runoff to the Great Barrier Reefs. Tech. rep., Australian Institute of Marine Science, Queensland, $334 \mathrm{p}$.

Gillibrand, P. A., Herzfeld, M., 2016. A mass-conserving advection scheme for offline simulation of tracer transport in coastal ocean models. Env. Model. Soft. 101, 1-16.

Gustafsson, M. S. M., Baird, M. E., Ralph, P. J., 2013. The interchangeability of autotrophic and heterotrophic nitrogen sources in scleractinian coral symbiotic relationships: a numerical study. Ecol. Model. 250, 183-194.

Gustafsson, M. S. M., Baird, M. E., Ralph, P. J., 2014. Modelling photoinhibition and bleaching in Scleractinian coral as a function of light, temperature and heterotrophy. Limnol. Oceanogr. 59, 603-622.

Herzfeld, M., 2015. Methods for freshwater riverine input into regional ocean models. Ocean Model. 90, 1 - 15.

Herzfeld, M., Andrewartha, J., Baird, M., Brinkman, R., Furnas, M., Gillibrand, P., Hemer, M., Joehnk, K., Jones, E., McKinnon, D., Margvelashvili, N., Mongin, M., Oke, P., Rizwi, F., Robson, B., Seaton, S., Skerratt, J., Tonin, H., Wild-Allen, K., 2016. eReefs Marine Modelling: Final Report, CSIRO, Hobart 497 pp. http://www.marine.csiro.au/cem/gbr4/eReefs_Marine_Modelling.pdf rm. Tech. rep.

Herzfeld, M., Gillibrand, P., 2015. Active open boundary forcing using dual relaxation time-scales in downscaled ocean models. Ocean Model. 89, 71-83. Hill, R., Brown, C. M., DeZeeuw, K., Campbell, D. A., Ralph, P. J., 2011. Increased rate of D1 repair in coral symbionts during bleaching is insufficient to counter accelerated photo-inactivation. Limnol. Oceanogr. 56, 139-146. 
Hochberg, E. J., Apprill, A. M., Atkinson, M. J., Bidigare, R. R., 2006. Biooptical modeling of photosynthetic pigments in corals. Coral Reefs 25, 99109.

Hock, K., Wolff, N. H., Ortiz, J. C., Condie, S. A., Anthony, K. R. N., Blackwell, P. G., Mumby, P. J., 2017. Connectivity and systemic resilience of the Great Barrier Reef. PLoS Biol. 11, e2003355.

Hoegh-Guldberg, O., 1999. Climate change, coral bleaching and the future of the world's coral reefs. Mar. Fresh. Res. 50, 839-866.

Hughes, T. P., Kerry, J. T., Simpson, T., 2017. Large-scale bleaching of corals on the Great Barrier Reef. Ecology.

URL http://dx.doi.org/10.1002/ecy. 2092

Kirk, J. T. O., 1975. A theoretical analysis of the contribution of algal cells to the attenuation of light within natural waters. I. General treatment of suspensions of pigmented cells. New Phytol. 75, 11-20.

Kirk, J. T. O., 1994. Light and Photosynthesis in Aquatic Ecosystems, 2nd Edition. Cambridge University Press, Cambridge.

Lilley, R. M., Ralph, P. J., Larkum, A. W. D., 2010. The determination of activity of the enzyme rubisco in cell extracts of the dinoflagellate alga symbiodinium sp. by manganese chemiluminescence and its response to short-term thermal stress of the alga. Plant, Cell \& Environment 33 (6), 995-1004.

Liu, G., Heron, S. F., Eakin, C. M., Muller-Karger, F. E., Vega-Rodriguez, M., Guild, L., Cour, J. L. D. L., Geiger, E. F., Skirving, W. J., Burgess, T. F. R., 2014. Reef-scale Thermal Stress Monitoring of Coral Ecosystems: New 5-km Global Products from NOAA Coral Reef Watch. Remote Sens. 6, 11579-11606.

Liu, Z., Yan, H., Wang, K., Kuang, T., Zhang, J., Gui, L., An, X., Chang, W., 2004. Crystal structure of spinach major light-harvesting complex at $2.72 \AA$ 
resolution. Nature 428, 287-292.

Madden, C. J., Kemp, W. M., 1996. Ecosystem model of an estuarine submersed plant community: calibration and simulation of eutrophication responses. Estuaries 19, 457-474.

Margvelashvili, N., Herzfeld, M., Rizwi, F., Mongin, M., Baird, M., Jones, E., Schaffelke, B., King, E., Schroeder, T., 2016. Emulator-assisted data assimilation in complex models. Ocean Dyn. 66, 1109-1124.

Matz, M., Treml, E. A., Aglyamova, G. V., Bay, L. K., 2018. Potential and limits for rapid genetic adaptation to warming in a Great Barrier Reef coral. PLOS Genetics 14, e1007220.

McNeil, M. A., Webster, J. M., Beaman, R. J., Graham, T. L., 2016. New constraints on the spatial distribution and morphology of the Halimeda bioherms of the Great Barrier Reef, Australia. Coral Reefs 35, 1343-1355.

Mongin, M., Baird, M. E., Tilbrook, B., Matear, R. J., Lenton, A., Herzfeld, M., Wild-Allen, K. A., Skerratt, J., Margvelashvili, N., Robson, B. J., Duarte, C. M., Gustafsson, M. S. M., Ralph, P. J., Steven, A. D. L., 2016. The exposure of the Great Barrier Reef to ocean acidification. Nature Communications 7, 10732 .

Monismith, S. G., Davis, K. A., Shellenbarger, G. G., Hench, J. L., Nidzieko, N. J., Santoro, A. E., Reidenbach, M. A., Rosman, J. H., Holtzman, R., Martens, C. S., Lindquist, N. L., Southwell, M. W., Genin, A., 2010. Flow effects on benthic grazing on phytoplankton by a Caribbean reef. Limnol. Oceanogr. 55, 1881-1892.

Muller, E. B., Sebastiaan, A. L., Kooijman, M., Edmunds, P. J., Doyle, F. J., Nisbet, R. M., 2009. Dynamic energy budgets in syntrophic symbiotic relationships between heterotrophic hosts and photoautotrophic symbionts. J. Theor. Biol. 259, 44-57. 
Muller-Parker, G., Cook, C. B., D'Elia, C. F., 1994. Elemental composition of the coral Pocillopora damicornis exposed to elevated seawater ammonium. Pac. Sci. 48, 234-246.

Murphy, C. D., Ni, G., Li, G., Barnett, A., Xu, K., Grant-Burt, J., Liefer, J. D., Suggett, D. J., Campbell, D. A., 2017. Quantitating active photosystem II reaction center content from fluorescence induction transients. Limnol. Oceanogr. Meth. 15, 54-69.

Nielsen, M. V., Sakshaug, E., 1993. Photobiological studies of Skeletonema costatum adapted to spectrally different light regimes. Limnol. Oceanogr. $38,1576-1581$.

Raven, J. A., 1997. Phagotrophy in phototrophs. Limnol. Oceanogr. 42, 198205.

Redfield, A. C., Ketchum, B. H., Richards, F. A., 1963. The influence of organisms on the composition of sea-water. In: Hill, N. (Ed.), The sea, 2nd Edition. Wiley, pp. 26-77.

Ribes, M., Atkinson, M. J., 2007. Effects of water velocity on picoplankton uptake by coral reef communities. Coral Reefs 26, 413-421.

Ridgway, K. R., Dunn, J. R., 2003. Mesoscale structure of the mean East Australian Current System and its relationship with topography. Prog. Oceanogr, 56, 189-222.

Roelfsema, C., Kovacs, E., Ortiz, J. C., Wolff, N. H., Callaghan, D., Wettle, M., Ronan, M., Hamylton, S. M., Mumby, P. J., Phinn, S., 2018. Coral reef habitat mapping: A combination of object-based image analysis and ecological modelling. Remote Sensing of Environment 208, 27-41.

Schiller, A., Herzfeld, M., Brinkman, R., Stuart, G., Jan. 2014. Monitoring, predicting and managing one of the seven natural wonders of the world. Bull. Am. Meteor. Soc., 23-30. 
Skerratt, J., Mongin, M., Wild-Allen, K. A., Baird, M. E., Robson, B. J., Schaffelke, B., Soja-Woźniak, M., Margvelashvili, N., Davies, C. H., Richardson, A. J., Steven, A. D. L., submitted. Plankton and nutrient dynamics on the Great Barrier Reef: Skill assessment and analysis of the eReefs biogeochemical model. J. Mar. Sys. , .

Skirving, W., Enrquez, S., Hedley, J. D., Dove, S., Eakin, C. M., Mason, R. A. B., Cour, J. L. D. L., Liu, G., Hoegh-Guldberg, O., Strong, A. E., Mumby, P. J., Iglesias-Prieto, R., 2018. Remote sensing of coral bleaching using temperature and light: progress towards an operational algorithm. Remote Sens. 10, 18.

Suggett, D. J., MacIntyre, H. L., Kana, T. M., Geider, R. J., 2009. Comparing electron transport with gas exchange: parameterising exchange rates between alternative photosynthetic currencies for eukaryotic phytoplankton. Aquat. Microb. Ecol. 56, 147-162.

Suggett, D. J., Warner, M. E., Smith, D. J., Davey, P., Hennige, S., Baker, N. R., 2008. Photosynthesis and production of hydrogen peroxide by Symbiodinium (Pyrrhophyta) phylotypes with different thermal tolerances. J. Phycol. 44, 948-956.

Tolleter, D., Seneca, F. O., DeNofrio, J. C., Krediet, C. J., Palumbi, S. R., Pringle, J. R., Grossman, A. R., 2013. Coral bleaching independent of photosynthetic activity. Current Biol. 23, 1782 - 1786.

Van Leer, B., 1977. Towards the ultimate conservative difference scheme. IV. A new approach to numerical convection. J. Comp. Phys. 23, 276 - 299. van Oppen, M. J. H., Gates, R. D., Blackall, L. L., Cantin, N., Chakravarti, L. J., Chan, W. Y., Cormick, C., Crean, A., Damjanovic, K., Epstein, H., Harrison, P. L., Jones, T. A., Miller, M., Pears, R. J., Peplow, L. M., Raftos, D. A., Schaffelke, B., Stewart, K., Torda, G., Wachenfeld, D., Weeks, A. R., 
Putnam, H. M., 2017. Shifting paradigms in restoration of the world's coral reefs. Global Change Biology 23 (9), 3437-3448.

URL http://dx.doi.org/10.1111/gcb.13647

van Woesik, R., Shiroma, K., Koksal, S., 2010. Phenotypic variance predicts symbiont population densities in corals: A modelling approach. PLOS One $5, \mathrm{e} 9185$.

Wild-Allen, K., Skerratt, J., Whitehead, J., Rizwi, F., Parslow, J., 2013. Mechanisms driving estuarine water quality: a 3D biogeochemical model for informed management. Est. Coast. Shelf Sci. 135, 33-45.

Wyatt, A. S. J., Lowe, R. J., Humphries, S., Waite, A. M., 2010. Particulate nutrient fluxes over a fringing coral reef: relevant scales of phytoplankton production and mechanisms of supply. Mar. Ecol. Prog. Ser. 405, 113-130.

Zhang, Z., Lowe, R., Falter, J., Ivey, G., 2011. A numerical model of waveand current-driven nutrient uptake by coral reef communities. Ecol. Mod. $222,1456-1470$. 
Table A.1. Model state variables. Note that water column variables are 3 dimensional, benthic variables are 2 dimensional, and unnormalised reserves are per cell.

\begin{tabular}{lcc}
\hline \hline Variable & Symbol & $\mathrm{Units}^{2}$ \\
\hline Dissolved inorganic nitrogen (DIN) & $N$ & $\mathrm{mg} \mathrm{N} \mathrm{m}^{-3}$ \\
Dissolved inorganic phosphorus (DIP) & $P$ & $\mathrm{mg} \mathrm{P} \mathrm{m}^{-3}$ \\
Zooxanthellae biomass & $C S$ & $\mathrm{mg} \mathrm{N} \mathrm{m}^{-2}$ \\
Reserves of nitrogen & $R_{N}$ & $\mathrm{mg} \mathrm{N} \mathrm{cell}^{-1}$ \\
Reserves of phosphorus & $R_{P}$ & $\mathrm{mg} \mathrm{P} \mathrm{cell}^{-1}$ \\
Reserves of carbon & $R_{C}$ & $\mathrm{mg} \mathrm{C} \mathrm{cell}^{-1}$ \\
Coral biomass & $C H$ & $\mathrm{~g} \mathrm{~N} \mathrm{~m}^{-2}$ \\
Suspended phytoplankton biomass & $B$ & $\mathrm{mg} \mathrm{N} \mathrm{m}^{-3}$ \\
Suspended zoooplankton biomass & $Z$ & $\mathrm{mg} \mathrm{N} \mathrm{m}^{-3}$ \\
Suspended detritus at 106:16:1 & $D_{R e d}$ & $\mathrm{mg} \mathrm{N} \mathrm{m}^{-3}$ \\
Macroalgae biomass & $\mathrm{MA}$ & $\mathrm{mg} \mathrm{N} \mathrm{m}^{-3}$ \\
Temperature & $T$ & ${ }^{\circ} \mathrm{C}^{-3}$ \\
Absolute salinity & $S_{A}$ & $\mathrm{~kg} \mathrm{~m}^{-3}$ \\
zooxanthellae chlorophyll $a$ concentration & $C h l$ & $\mathrm{mg} \mathrm{m}^{-2}$ \\
zooxanthellae diadinoxanthin concentration & $X_{p}$ & $\mathrm{mg} \mathrm{m}^{-2}$ \\
zooxanthellae diatoxanthin concentration & $X_{h}$ & $\mathrm{mg} \mathrm{m}^{-2}$ \\
Oxidised reaction centre concentration & $Q_{\mathrm{ox}}$ & $\mathrm{mg} \mathrm{m}^{-2}$ \\
Reduced reaction centre concentration & $Q_{\mathrm{red}}$ & $\mathrm{mg} \mathrm{m}^{-2}$ \\
Inhibited reaction centre concentration & $Q_{\mathrm{in}}$ & $\mathrm{mg} \mathrm{m}^{-2}$ \\
Reactive oxygen species concentration & $\mathrm{ROS}$ & $\mathrm{mg} \mathrm{m}^{-2}$ \\
Chemical oxygen demand & $C O D$ & $\mathrm{mg} \mathrm{O}_{2} \mathrm{~m}^{-3}$ \\
\hline \hline
\end{tabular}


Table A.2. Derived variables for the coral polyp model.

\begin{tabular}{|c|c|c|}
\hline Variable & Symbol & Units \\
\hline Downwelling irradiance & $E_{d}$ & $\mathrm{~W} \mathrm{~m}^{-2}$ \\
\hline Maximum reserves of nitrogen & $R_{N}^{\max }$ & $\operatorname{mg} \mathrm{N}$ cell ${ }^{-1}$ \\
\hline Maximum reserves of phosphorus & $R_{P}^{\max }$ & mg $\mathrm{P}$ cell $^{-1}$ \\
\hline Maximum reserves of carbon & $R_{C}^{\max }$ & $\mathrm{mg} \mathrm{C}$ cell $^{-1}$ \\
\hline Normalised reserves of nitrogen & $R_{N}^{*} \equiv R_{N} / R_{N}^{\max }$ & - \\
\hline Normalised reserves of phosphorus & $R_{P}^{*} \equiv R_{P} / R_{P}^{\max }$ & - \\
\hline Normalised reserves of carbon & $R_{C}^{*} \equiv R_{C} / R_{C}^{\max }$ & - \\
\hline Intracellular chlorophyll $a$ concentration & $c_{i}$ & $\mathrm{mg} \mathrm{m}^{-3}$ \\
\hline Intracellular diadinoxanthin concentration & $x_{p}$ & $\operatorname{mg~} \mathrm{m}^{-3}$ \\
\hline Intracellular diatoxanthin concentration & $x_{h}$ & $\operatorname{mg~} \mathrm{m}^{-3}$ \\
\hline Total reaction centre concentration & $Q_{\mathrm{T}}$ & $\mathrm{mg} \mathrm{m}^{-2}$ \\
\hline Total active reaction centre concentration & $Q_{\mathrm{a}}$ & $\mathrm{mg} \mathrm{m}^{-2}$ \\
\hline Concentration of zooxanthellae cells & $n$ & cell $\mathrm{m}^{-2}$ \\
\hline Thickness of the bottom water column layer & $h_{w c}$ & $\mathrm{~m}$ \\
\hline Effective projected area fraction & $A_{e f f}$ & $\mathrm{~m}^{2} \mathrm{~m}^{-2}$ \\
\hline Area density of zooxanthellae cells & $n_{C S}$ & cell $\mathrm{m}^{-2}$ \\
\hline Absorption cross-section & $\alpha$ & $\mathrm{m}^{2} \operatorname{cell}^{-1}$ \\
\hline Rate of photon absorption & $k_{I}$ & mol photon cell ${ }^{-1} \mathrm{~s}^{-1}$ \\
\hline Photon-weighted average opaqueness & $\bar{\chi}$ & - \\
\hline Maximum Chl. synthesis rate & $k_{\mathrm{Chl}}^{\max }$ & $\operatorname{mg}$ Chl m${ }^{-3} \mathrm{~d}^{-1}$ \\
\hline Density of water & $\rho$ & $\mathrm{kg} \mathrm{m}^{-3}$ \\
\hline Bottom stress & $\tau$ & $\mathrm{N} \mathrm{m}^{-2}$ \\
\hline Schmidt number & $\mathrm{Sc}$ & - \\
\hline Mass transfer rate coefficient for particles & $S_{\text {part }}$ & $\mathrm{m} \mathrm{d}^{-1}$ \\
\hline Heterotrophic feeding rate & $G$ & $\mathrm{~g} \mathrm{~N} \mathrm{~m} \mathrm{~m}^{-2} \mathrm{~d}^{-1}$ \\
\hline Wavelength & $\lambda$ & $\mathrm{nm}$ \\
\hline Translocation fraction & $f_{\text {tran }}$ & - \\
\hline Active fraction of oxidised reaction centres & $a_{Q_{o x}}^{*}$ & - \\
\hline
\end{tabular}


Table A.3. Equations for the interactions of coral host, symbiont and environment excluding bleaching loss terms that appear in Table A.6. The term $C S / m_{N}$ is the concentration of zoothanxellae cells. The equation for organic matter formation gives the stoichiometric constants; $12 \mathrm{~g} \mathrm{C} \mathrm{mol} \mathrm{C}^{-1} ; 32 \mathrm{~g} \mathrm{O}$ mol O$_{2}^{-1}$.

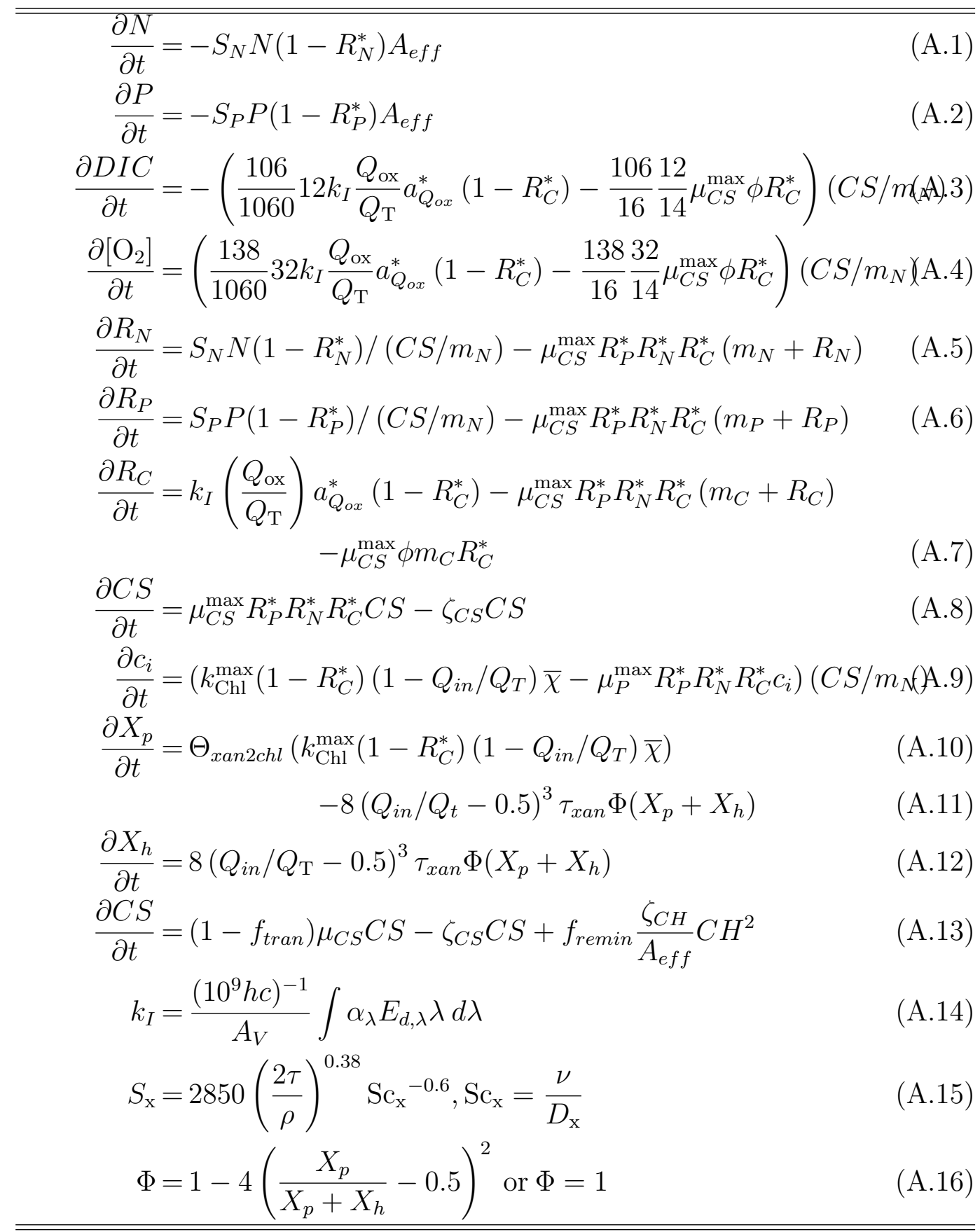


Table A.4. Equations for the coral polyp model. The term $C S / m_{N}$ is the concentration of zoothanxellae cells. The equation for organic matter formation gives the stoichiometric constants; $12 \mathrm{~g} \mathrm{C} \mathrm{mol} \mathrm{C}^{-1} ; 32 \mathrm{~g} \mathrm{O} \mathrm{mol} \mathrm{O}_{2}^{-1}$. Other constants and parameters are defined in Table A.8.

\begin{aligned} \hline \hline$\frac{\partial C H}{\partial t} & =G^{\prime}-\frac{\zeta_{C H}}{A_{e f f}} C H^{2} \\ \frac{\partial B}{\partial t} & =-S_{\text {part }} A_{e f f} B \frac{G^{\prime}}{G} / h_{w c} \\ \frac{\partial Z}{\partial t} & =-S_{\text {part }} A_{e f f} Z \frac{G^{\prime}}{G} / h_{w c} \\ \frac{\partial D_{\text {Red }}}{\partial t} & =\left(-S_{\text {part }} A_{e f f} D_{\text {Red }} \frac{G^{\prime}}{G}+\left(1-f_{\text {remin }}\right) \frac{\zeta_{C H}}{A_{e f f}} C H^{2}\right) / h_{w c} \\ f_{\text {tran }} & =\frac{\pi r_{C S}^{2} n_{C S}}{2 C H \Omega_{C H}} \\ G & =S_{\text {part }} A_{e f f}\left(B+Z+D_{\text {Red }}\right) \\ G^{\prime} & =\min \left[\min \left[\mu_{C H}^{\max } C H-f_{\text {tran }} \mu_{C S} C S-\zeta_{C S} C S, 0\right], G\right] \\ A_{e f f} & =1-\exp \left(-\Omega_{C H} C H\right)\end{aligned}$

Table A.5. Reaction centre dynamics. Bleaching loss terms appear in Table A.6.

$\begin{aligned} \frac{\partial Q_{\mathrm{ox}}}{\partial t} & =-k_{I} n m_{\mathrm{RCII}}\left(\frac{Q_{\mathrm{ox}}}{Q_{\mathrm{T}}}\right)\left(1-a_{Q_{o x}}^{*}\left(1-R_{C}^{*}\right)\right)+f_{2}(T) R_{N}^{*} R_{P}^{*} R_{C}^{*} Q_{\mathrm{i}}(\mathrm{A} .25) \\ \frac{\partial Q_{\mathrm{red}}}{\partial t} & =k_{I} n m_{\mathrm{RCII}}\left(\frac{Q_{\mathrm{ox}}}{Q_{\mathrm{T}}}\right)\left(1-a_{Q_{o x}}^{*}\left(1-R_{C}^{*}\right)\right)-k_{I} n m_{R C I I} \frac{Q_{\mathrm{red}}}{Q_{T}} \\ \frac{\partial Q_{\mathrm{in}}}{\partial t} & =-268 m_{R C I I} Q_{\mathrm{in}}+k_{I} n m_{R C I I} \frac{Q_{\mathrm{red}}}{Q_{T}} \\ \frac{\partial[\mathrm{ROS}]}{\partial t} & =-f(T) R_{N}^{*} R_{P}^{*} R_{C}^{*}[\mathrm{ROS}]+32 \frac{138}{106} \frac{1}{10} k_{I} n m_{\mathrm{RCII}}\left(\frac{Q_{\mathrm{in}}}{Q_{\mathrm{T}}}\right)\end{aligned}$


Table A.6. Equations describing the expulsion of zooxanthellae, and the resulting release of inorganic and organic molecules into the bottom water column layer.

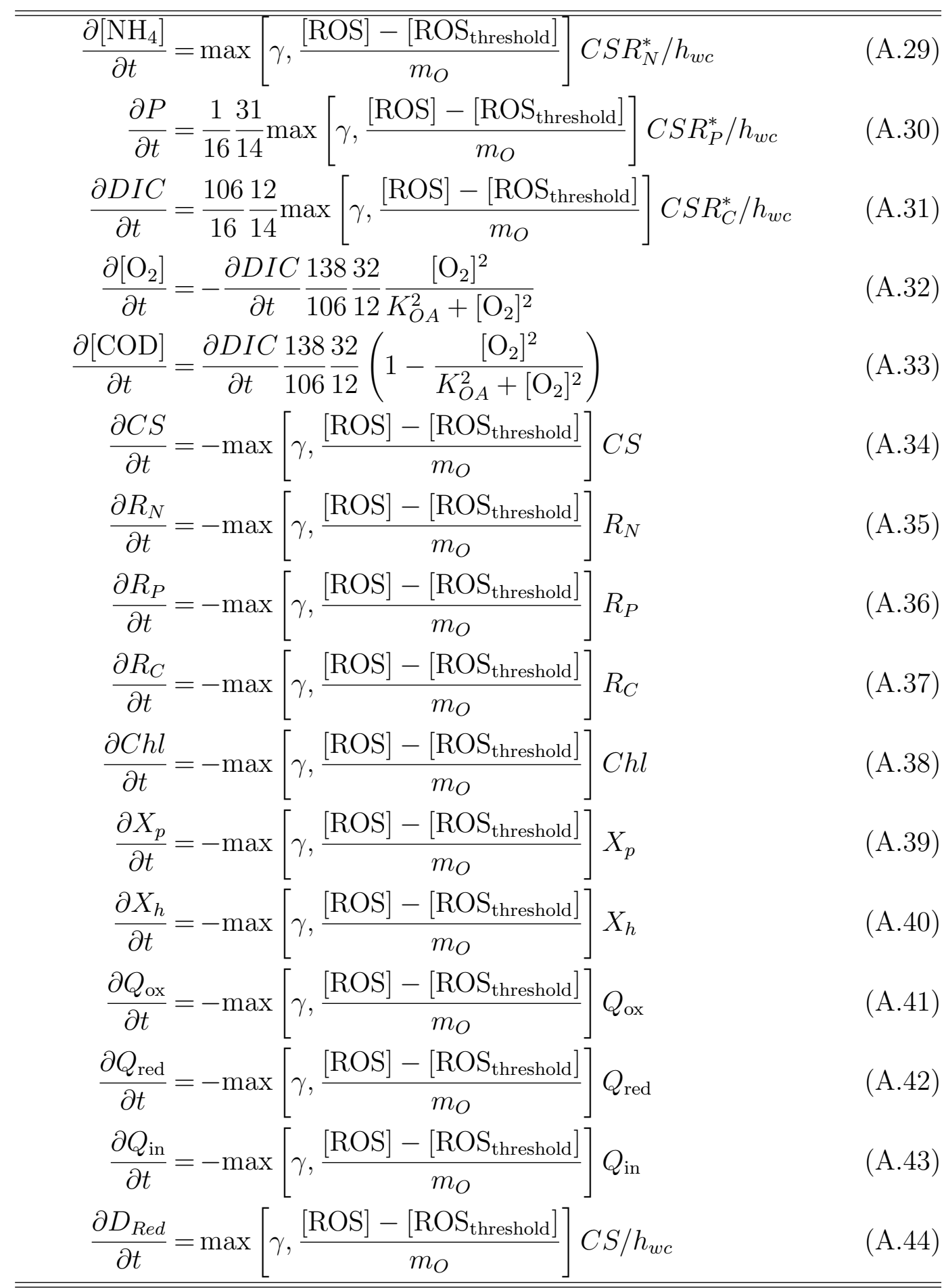


Table A.7. Constants and parameter values used to model coral polyps. $V$ is zooxanthellae cell volume in $\mu \mathrm{m}^{3} .{ }^{a}$ Fig. $5,{ }^{c}$ Redfield et al. (1963) and Kirk (1994), ${ }^{d}$ Finkel (2001), ${ }^{e}$ Ribes and Atkinson (2007); Wyatt et al. (2010), ${ }^{f, g}$ Gustafsson et al. (2013, 2014).

\begin{tabular}{|c|c|c|}
\hline & Symbol & Value \\
\hline \multicolumn{3}{|l|}{ Constants } \\
\hline Molecular diffusivity of $\mathrm{NO}_{3}$ & $D$ & $f\left(T, S_{A}\right) \sim 17.5 \times 10^{-10} \mathrm{~m}^{2} \mathrm{~s}^{-1}$ \\
\hline Speed of light & $c$ & $2.998 \times 10^{8} \mathrm{~m} \mathrm{~s}^{-1}$ \\
\hline Planck constant & $h$ & $6.626 \times 10^{-34} \mathrm{~J} \mathrm{~s}^{-1}$ \\
\hline Avagadro constant & $A_{V}$ & $6.02 \times 10^{23} \mathrm{~mol}^{-1}$ \\
\hline${ }^{a}$ Pigment-specific absorption coefficients & $\gamma_{\lambda}$ & $f(\operatorname{pig}, \lambda) \mathrm{m}^{-1}\left(\mathrm{mg} \mathrm{m}^{-3}\right)^{-1}$ \\
\hline Kinematic viscosity of water & $\nu$ & $f\left(T, S_{A}\right) \sim 1.05 \times 10^{-6} \mathrm{~m}^{2} \mathrm{~s}^{-1}$ \\
\hline \multicolumn{3}{|l|}{ Parameters } \\
\hline${ }^{b}$ Nitrogen content of zooxanthellae cells & $m_{N}$ & $5.77 \times 10^{-12} \mathrm{~mol} \mathrm{~N}$ cell $^{-1}$ \\
\hline${ }^{c}$ Carbon content of zooxanthellae cells & $m_{C}$ & $(106 / 16) m_{N}$ mol C cell ${ }^{-1}$ \\
\hline${ }^{d}$ Maximum intracellular Chl concentration & $c_{i}^{\max }$ & $3.15 \times 10^{6} \mathrm{mg} \mathrm{Chl} \mathrm{m}{ }^{-3}$ \\
\hline Radius of zooxanthellae cells & $r_{C S}$ & $5 \mu \mathrm{m}$ \\
\hline Maximum growth rate of coral & $\mu_{C H}^{\max }$ & $0.05 \mathrm{~d}^{-1}$ \\
\hline${ }^{e}$ Rate coefficient of particle capture & $S_{\text {part }}$ & $3.0 \mathrm{~m} \mathrm{~d}^{-1}$ \\
\hline Maximum growth rate of zooxanthellae & $\mu_{C S}^{\max }$ & $0.4 \mathrm{~d}^{-1}$ \\
\hline Quadratic mortality coefficient of polyps & $\zeta_{C H}$ & $0.01 \mathrm{~d}^{-1}\left(\mathrm{~g} \mathrm{~N} \mathrm{~m}^{-2}\right)^{-1}$ \\
\hline Linear mortality of zooxanthellae & $\zeta_{C S}$ & $0.04 \mathrm{~d}^{-1}$ \\
\hline${ }^{g}$ Remineralised fraction of coral mortality & $f_{\text {remin }}$ & 0.5 \\
\hline Nitrogen-specific host area coefficient of polyps & $\Omega_{C H}$ & $2.0 \mathrm{~m}^{2} \mathrm{~g} \mathrm{~N}^{-1}$ \\
\hline Fractional (of $\mu_{C S}^{\max }$ ) respiration rate & $\phi$ & 0.1 \\
\hline
\end{tabular}


Table A.8. Constants and parameter values used in the coral bleaching model. ${ }^{a} \mathrm{In}$ Suggett et al. (2009). ${ }^{b}$ ratio of constant terms in multivariate analysis in Hochberg et al. (2006). ${ }^{c}$ Fitted parameter based on the existence of non-bleaching threshold (Suggett et al., 2009), and a comparison of observed bleaching and model output in the $\sim 1 \mathrm{~km}$ model.

\begin{tabular}{lcc}
\hline \hline & Symbol & Value \\
\hline Constants & & \\
Parameters & & \\
Maximum growth rate of zooxanthellae & $\mu_{C S}^{m a x}$ & $1 \mathrm{~d}^{-1}$ \\
Rate coefficient of xanthophyll switching & $\tau_{\text {xan }}$ & $1 / 600 \mathrm{~s}^{-1}$ \\
${ }^{a}$ Atomic ratio of Chl a to RCII in Symbiodinium & $A_{\mathrm{RCII}}$ & $500 \mathrm{~mol} \mathrm{Chl} \mathrm{mol} \mathrm{RCII}^{-1}$ \\
${ }^{a}$ Stoichiometric ratio of RCII units to photons & $m_{\mathrm{RCII}}$ & $0.1 \mathrm{~mol} \mathrm{RCII} \mathrm{mol} \mathrm{photon}^{-1}$ \\
Maximum rate of zooxanthellae expulsion & $\gamma$ & $1 \mathrm{~d}^{-1}$ \\
Oxygen half-saturation for aerobic respiration & $K_{O A}$ & $500 \mathrm{mg} \mathrm{O} \mathrm{m}^{-3}$ \\
Molar mass of Chl a & $M_{\text {Chla }}$ & $893.49 \mathrm{~g} \mathrm{~mol}^{-1}$ \\
${ }^{b}$ Ratio of Chl a to xanthophyll & $\Theta_{\text {chla2xan }}$ & $0.2448 \mathrm{mg} \mathrm{Chl} \mathrm{mg} \mathrm{X}^{-1}$ \\
${ }^{b}$ Ratio of Chl a to Chl c & $\Theta_{\text {chla2chlc }}$ & $0.1273 \mathrm{mg} \mathrm{Chl-a} \mathrm{mg} \mathrm{Chl-c}^{-1}$ \\
${ }^{b}$ Ratio of Chl a to peridinin & $\Theta_{\text {chla2per }}$ & $0.4733 \mathrm{mg} \mathrm{Chl} \mathrm{mg}^{-1}$ \\
${ }^{b}$ Ratio of Chl a to $\beta$-carotene & $\Theta_{\text {chla2caro }}$ & $0.0446 \mathrm{mg} \mathrm{Chl} \mathrm{mg}^{-1}$ \\
${ }^{c}$ Lower limit of ROS bleaching & {$\left[\mathrm{ROS}_{\text {threshold }}\right]$} & $5 \times 10^{-4} \mathrm{mg} \mathrm{O} \mathrm{cell}^{-1}$ \\
\hline \hline
\end{tabular}

